\title{
THE QUALITY OF THE CATALAN AND SPANISH EDUCATION SYSTEMS: A PERSPECTIVE FROM PISA
}

\author{
Antonio Ciccone \\ Walter Garcia-Fontes
}


The Public-Private Center is a Research Center based at IESE Business School. Its mission is to develop research that analyses the relationships between the private and public sectors primarily in the following areas: regulation and competition, innovation, regional economy and industrial politics and health economics.

Research results are disseminated through publications, conferences and colloquia. These activities are aimed to foster cooperation between the private sector and public administrations, as well as the exchange of ideas and initiatives.

The sponsors of the SP-SP Center are the following:

- Accenture

- Ajuntament de Barcelona

- Caixa Manresa

- Cambra Oficial de Comerç, Indústria i Navegació de Barcelona

- Consell de l'Audiovisual de Catalunya

- Departamento de Economía y Finanzas de la Generalitat de Catalunya

- Departamento de Innovación, Universidades y Empresa de la Generalitat de Catalunya

- Diputació de Barcelona

- Endesa

- Fundació AGBAR

- Garrigues

- Mediapro

- Microsoft

- Sanofi Aventis

- VidaCaixa

The contents of this publication reflect the conclusions and findings of the individual authors, and not the opinions of the Center's sponsors. 


\title{
THE QUALITY OF THE CATALAN AND SPANISH EDUCATION SYSTEMS: A PERSPECTIVE FROM PISA
}

\author{
Antonio Ciccone ${ }^{1}$ \\ Walter Garcia-Fontes ${ }^{2}$
}

\begin{abstract}
For Catalonia and Spain, public perception is that the PISA reports show that their education systems are underperforming. The goal of this chapter is to quantify how much of the Catalan and Spanish PISA score can be attributed to the education levels of parents and what part must instead be explained by other factors. To do so we use standard statistical techniques to examine how the Catalan and Spanish PISA score would have compared with other countries and regions if all had the same parental education levels and immigration levels. For Spain the main results show that there is a sizable increase in PISA scores relative to the rest of Europe when parental schooling is accounted for. But Spain's performance is rather poor to start out with and only rises to somewhat above average when accounting for parental education levels. For Catalonia accounting for parental education levels leads to small improvements in the PISA score compared to other Spanish regions and to Flanders, Lombardy, and Denmark. Moreover, immigration or the concentration of immigrants at some schools accounts for little of the below average performance of Catalonia.
\end{abstract}

Keywords: PISA, Catalonia, Spain.

\footnotetext{
${ }^{1}$ Universitat Pompeu Fabra and ICREA

${ }^{2}$ Universitat Pompeu Fabra
} 


\section{THE QUALITY OF THE CATALAN AND SPANISH EDUCATION SYSTEMS: A PERSPECTIVE FROM PISA}

\section{Introduction}

The OECD coordinated Programme for International Student Assessment (PISA) has made the public aware that teenagers have much better science, math, and reading skills in some places than others. For Catalonia and Spain, public perception is that the PISA reports show that their education systems are underperforming. Their 2006 average scores have been below the OECD average in all three subject areas, and did not improve with respect to the 2000 and 2003 reports. This should be an important concern as there is a consensus that the skills of the labor force are key for high productivity and wages. ${ }^{1}$ But to what extent does the responsibility for the PISA performance of Catalan and Spanish teenagers lie within the education system?

In a meeting organized by The Economist, Spain's Prime Minister Zapatero argued that "the main determinant of the education of each generation is the education of the parents, together with the education received in the educational system." He added that in the recent history of Spain there were many generations with low education levels. ${ }^{2}$ These remarks came shortly after publication of the 2006 PISA results, and it seems probable that the Prime Minister was suggesting that the poor performance of Spain was partly due to the still relatively low education levels of Spanish parents. Spain's Minister of Education, Mercedes Cabrera, even argued that the Spanish education system was doing well once teenagers' family backgrounds were taken into account. ${ }^{3}$ When commenting on the Catalan PISA results, the Catalan Secretary of Education, Ernest Maragall, argued "that Catalonia is a changing region due to the growth, mobility and diversity of its population." This probably reflects the perception that the large immigration flows between 1996 and 2006 period could have affected the Catalan PISA performance.

\footnotetext{
${ }^{1}$ For a quantitative analysis of the economic effects of improvements in school quality, see Hanushek, E. (2005).

${ }^{2}$ La Vanguardia, 4 December 2007.

${ }^{3}$ El País, 5 December 2007.

${ }^{4}$ Generalitat de Catalunya (2007).
} 
Education also takes place at home and it is therefore not surprising that many studies have found that the educational attainment of parents and immigration status plays a role in individual performance. Our goal here is to quantify how much of the Catalan and Spanish PISA score can be attributed to the education levels of parents and how much must instead be explained by other factors. To do so we use standard statistical techniques to ask the following question: How would the Catalan and Spanish PISA score have compared with other countries and regions if all had the same parental education levels and immigration levels?

For Spain our comparisons are within Europe. The starting position is that Spain performed 11 points below average in science, 14 points below average in math, and 24 points below average in reading. Among the 23 European countries in our sample, this puts Spain in the bottom third in science and the bottom quartile in math; in reading, only two countries did worse. But the situation changes when we consider teenagers from a similar family background. For example, if we consider teenagers whose parents left school with a lower secondary school degree and were born in the country, Spain is 13.9 points above average in science, 13 points above average in math, and 7.7 points above average in reading. These comparisons cannot be generalized of course as they concern just one specific group of students. But they do indicate that the Spanish PISA score may be below average partly because of the low educational attainments of parents. In fact we find that, accounting for the low education levels of Spanish parents, Spanish PISA performance is somewhat above average in science and math, and approximately average in reading.

Hence, low education levels of Spanish parents play a role for Spain's poor PISA performance. But it is important to note that, compared to the European average, Spain does relatively worse when we consider teenagers with college educated parents or parents with upper secondary school education, than when we consider teenagers with parents who have a lower secondary education. For example, Spanish teenagers with parents who have completed upper secondary school perform 5.2 points above average in science and 7.6 points above average in math. The children of college educated parents are at or below the average in both science and math. This indicates that the Spanish PISA performance in science and math need not automatically rise above average as parental education levels catch up to the European average. In fact, when we ask what Spain's PISA performance would be if parental education levels were equal to the European average, we find that more than half of the European countries in our sample would continue to do better than Spain in science and math.

For Catalonia our comparisons are with other Spanish regions that participated in PISA plus Lombardy, Flanders, and Denmark, which makes a group of 14 regions and countries. Catalonia does poorly in this group, either $3^{\text {rd }}$ or $4^{\text {th }}$ from the bottom depending on the subject tested. Accounting for parental education levels does not change the comparative performance of Catalonia significantly. Catalonia scores 12 points less than average in science and 14 less in math. Accounting for parental education levels, the same gaps are around 10 and 12 points respectively. The comparison with some of the leading performers is especially interesting. For example, Catalonia does around 45 points worse than Flanders in science and math. Controlling for parental education levels, this gap shrinks but is still 35 points. La Rioja and Castile and Leon outperform Catalonia in science and math by around 35 and 27 points respectively, although they have quite similar parental education levels. In reading, Catalonia is only somewhat worse than average to start out with and improves slightly when parental education is taken into account. 
We also examine to what extent PISA scores vary across countries and regions because of differences in immigration levels. For the comparison of Spain with other European countries, accounting for immigration makes little difference. Basically, this is because levels of immigration are similar in many European countries. The same result holds for the comparison of Catalonia with other Spanish regions that participated in PISA and Lombardy, Flanders, and Denmark. For the case of Catalonia, the concentration of immigrants at some schools has been an important concern. We show that while concentration of immigrant students is greater in Catalonia than in many other countries and regions, this is not an important factor behind the poor Catalan PISA performance.

The academic literature tends to find weak effects of educational expenditures on school performance. Our analysis yields similar results. Across Spanish regions participating in PISA, there is only a very weak (and statistically insignificant) effect of secondary school expenditures and PISA performance adjusted for parental education and immigration status. Across European countries there is a statistically significant but very small effect of secondary school expenditures on adjusted PISA scores. The setting that according to the academic literature is most conducive to school quality is school autonomy subject to performance evaluation. However, there is insufficient data on school and student characteristics to evaluate these hypotheses, specifically for Catalonia and Spain. Making progress in understanding the determinants of school quality within Catalonia or Spain will require that policy makers decide to implement rigorously designed school evaluation programs.

\section{Descriptive Statistics and Empirical Analysis}

\subsection{Parental Education Levels in Catalonia and Spain}

Table 1 shows the education levels of fathers and mothers in Spain and other European countries according to PISA 2006. 25\% of fathers in Spain have at most a primary school education or less. ${ }^{5}$ This share is very high by European standards-more than three times the European average-and only surpassed by Portugal. The situation for mothers can be seen to be very similar.

Table 2 contains the same statistics for Catalonia, other Spanish autonomous communities for which there is data, and, to allow for further comparisons, Denmark, Flanders, and Lombardy. Perhaps surprisingly, the share of fathers with less than primary school studies in Catalonia is above average and among the highest in Spain, only surpassed by Andalusia and the Rest of Spain (a residual category of Spanish regions that did not participate individually in PISA); see Table 2. The same is true for mothers. The differences with Denmark, Flanders, and Lombardy in parental education levels are quite large. But the differences with other Spanish regions are often small. For example, in Catalonia, the highest education level of 15\% of fathers and 13\% of mothers is primary schooling. In Spain's best-performing PISA region, La Rioja, the shares are not much smaller, $12 \%$ and $10 \%$ respectively.

\footnotetext{
${ }^{5}$ The European countries included correspond to European Union countries that participated in the PISA assessment, except for Poland where the schooling coding is slightly different.
} 


\section{Table 1}

Parental education levels (European sample)

\begin{tabular}{|c|c|c|c|c|c|c|c|c|c|c|}
\hline & \multicolumn{2}{|c|}{ No degree } & \multicolumn{2}{|c|}{ Primary School } & \multicolumn{2}{|c|}{ Basic Secondary } & \multicolumn{2}{|c|}{ Advanced Secondary } & \multicolumn{2}{|c|}{ College } \\
\hline & Fathers & Mothers & Fathers & Mothers & Fathers & Mothers & Fathers & Mothers & Fathers & Mothers \\
\hline Austria & 0.01 & 0.02 & 0.01 & 0.02 & 0.06 & 0.08 & 0.47 & 0.54 & 0.45 & 0.27 \\
\hline Belgium & 0.03 & 0.04 & 0.03 & 0.03 & 0.07 & 0.07 & 0.40 & 0.35 & 0.46 & 0.47 \\
\hline Czech Republic & 0.01 & 0.01 & 0.00 & 0.01 & 0.02 & 0.04 & 0.72 & 0.65 & 0.24 & 0.24 \\
\hline Denmark & 0.02 & 0.02 & 0.03 & 0.02 & 0.10 & 0.10 & 0.42 & 0.28 & 0.43 & 0.55 \\
\hline Estonia & 0.01 & 0.00 & 0.00 & 0.00 & 0.06 & 0.04 & 0.58 & 0.47 & 0.35 & 0.41 \\
\hline Finland & 0.02 & 0.01 & 0.06 & 0.04 & 0.10 & 0.07 & 0.23 & 0.17 & 0.59 & 0.68 \\
\hline France & 0.05 & 0.04 & 0.02 & 0.01 & 0.20 & 0.19 & 0.43 & 0.43 & 0.31 & 0.29 \\
\hline Germany & 0.04 & 0.04 & 0.00 & 0.00 & 0.17 & 0.17 & 0.40 & 0.44 & 0.39 & 0.27 \\
\hline Greece & 0.01 & 0.01 & 0.13 & 0.11 & 0.16 & 0.17 & 0.34 & 0.37 & 0.35 & 0.31 \\
\hline Hungary & 0.01 & 0.01 & 0.00 & 0.01 & 0.09 & 0.14 & 0.65 & 0.54 & 0.24 & 0.28 \\
\hline Ireland & 0.02 & 0.01 & 0.08 & 0.05 & 0.16 & 0.15 & 0.42 & 0.43 & 0.32 & 0.34 \\
\hline Italy & 0.01 & 0.01 & 0.06 & 0.05 & 0.34 & 0.33 & 0.40 & 0.45 & 0.19 & 0.19 \\
\hline Latvia & 0.01 & 0.01 & 0.01 & 0.00 & 0.05 & 0.03 & 0.61 & 0.47 & 0.33 & 0.43 \\
\hline Lithuania & 0.01 & 0.00 & 0.00 & 0.00 & 0.02 & 0.02 & 0.60 & 0.42 & 0.38 & 0.51 \\
\hline Luxembourg & 0.11 & 0.14 & 0.09 & 0.11 & 0.06 & 0.08 & 0.38 & 0.34 & 0.36 & 0.34 \\
\hline Netherlands & 0.03 & 0.03 & 0.05 & 0.05 & 0.11 & 0.13 & 0.38 & 0.35 & 0.43 & 0.35 \\
\hline Portugal & 0.31 & 0.30 & 0.18 & 0.18 & 0.14 & 0.16 & 0.21 & 0.23 & 0.16 & 0.18 \\
\hline Romania & 0.01 & 0.01 & 0.02 & 0.02 & 0.08 & 0.11 & 0.51 & 0.43 & 0.38 & 0.40 \\
\hline Slovak Republic & 0.01 & 0.01 & 0.00 & 0.00 & 0.03 & 0.05 & 0.75 & 0.68 & 0.20 & 0.20 \\
\hline Slovenia & 0.01 & 0.01 & 0.01 & 0.01 & 0.11 & 0.14 & 0.64 & 0.55 & 0.24 & 0.28 \\
\hline Spain & 0.09 & 0.08 & 0.16 & 0.16 & 0.22 & 0.25 & 0.26 & 0.27 & 0.27 & 0.24 \\
\hline Sweden & 0.03 & 0.02 & 0.02 & 0.01 & 0.16 & 0.10 & 0.28 & 0.24 & 0.51 & 0.61 \\
\hline United Kingdom & 0.02 & 0.02 & 0.02 & 0.01 & 0.10 & 0.06 & 0.48 & 0.46 & 0.38 & 0.41 \\
\hline Europe & 0.04 & 0.04 & 0.04 & 0.03 & 0.16 & 0.16 & 0.43 & 0.42 & 0.34 & 0.32 \\
\hline
\end{tabular}

Note: Proportion of individuals in each category. Source: PISA 2006. 


\section{Table 2}

Parental education levels (regions/countries sample)

\begin{tabular}{|c|c|c|c|c|c|c|c|c|c|c|}
\hline & \multicolumn{2}{|c|}{ No degree } & \multicolumn{2}{|c|}{ Primary School } & \multicolumn{2}{|c|}{ Basic Secondary } & \multicolumn{2}{|c|}{ Advanced Secondary } & \multicolumn{2}{|c|}{ College } \\
\hline & Fathers & Mothers & Fathers & Mothers & Fathers & Mothers & Fathers & Mothers & Fathers & Mothers \\
\hline Denmark & 0.02 & 0.02 & 0.03 & 0.02 & 0.10 & 0.10 & 0.42 & 0.28 & 0.43 & 0.55 \\
\hline Flanders & 0.03 & 0.03 & 0.03 & 0.02 & 0.07 & 0.06 & 0.44 & 0.38 & 0.44 & 0.46 \\
\hline Lombardy & 0.01 & 0.02 & 0.06 & 0.04 & 0.37 & 0.36 & 0.40 & 0.48 & 0.15 & 0.15 \\
\hline Andalusia & 0.16 & 0.15 & 0.23 & 0.24 & 0.18 & 0.23 & 0.21 & 0.24 & 0.22 & 0.16 \\
\hline Aragon & 0.05 & 0.03 & 0.11 & 0.11 & 0.25 & 0.30 & 0.28 & 0.29 & 0.30 & 0.29 \\
\hline Asturias & 0.05 & 0.03 & 0.10 & 0.08 & 0.22 & 0.25 & 0.33 & 0.35 & 0.31 & 0.28 \\
\hline Cantabria & 0.03 & 0.03 & 0.09 & 0.09 & 0.26 & 0.27 & 0.32 & 0.34 & 0.29 & 0.26 \\
\hline Castile and Leon & 0.05 & 0.04 & 0.13 & 0.11 & 0.26 & 0.27 & 0.29 & 0.30 & 0.28 & 0.28 \\
\hline Catalonia & 0.07 & 0.07 & 0.15 & 0.13 & 0.20 & 0.24 & 0.25 & 0.27 & 0.33 & 0.31 \\
\hline Galicia & 0.07 & 0.05 & 0.15 & 0.15 & 0.25 & 0.28 & 0.29 & 0.31 & 0.25 & 0.23 \\
\hline La Rioja & 0.04 & 0.03 & 0.12 & 0.10 & 0.27 & 0.30 & 0.27 & 0.30 & 0.30 & 0.28 \\
\hline Navarre & 0.06 & 0.04 & 0.12 & 0.10 & 0.22 & 0.25 & 0.26 & 0.30 & 0.34 & 0.30 \\
\hline Basque Country & 0.05 & 0.03 & 0.09 & 0.10 & 0.17 & 0.21 & 0.30 & 0.30 & 0.39 & 0.34 \\
\hline Rest of Spain & 0.09 & 0.07 & 0.15 & 0.16 & 0.23 & 0.26 & 0.27 & 0.28 & 0.25 & 0.23 \\
\hline All regions & 0.07 & 0.06 & 0.12 & 0.12 & 0.21 & 0.23 & 0.31 & 0.31 & 0.29 & 0.28 \\
\hline
\end{tabular}

Note: Proportion of individuals in each category. Source: PISA 2006.

\subsection{Immigration in Catalonia and Spain}

Table 3 assesses immigration levels in Spain. It gives the share of teenagers with at least one of the parents born abroad who were themselves born abroad (group 1) or born in the country (group 2). Spain does not look exceptional. It is somewhat above average in group 1, probably because immigration has been a relatively recent phenomenon in Spain, and somewhat below average in group 2. Table 3 also contains the share of students who speak a non-official language at home, which in Spain is below the European average. The last two columns in Table 3 contain two statistics on the concentration of immigrant students in schools; the share of schools with more than 10\% immigrant children, and the share of children at schools with more than $10 \%$ immigrant children. Spain is above the average but not exceptional, especially if one considers Western Europe. 


\section{Table 3}

Immigration statistics (European sample)

\begin{tabular}{|c|c|c|c|c|c|}
\hline & $\begin{array}{c}\text { Group } \\
1\end{array}$ & $\begin{array}{c}\text { Group } \\
2\end{array}$ & $\begin{array}{c}\text { Other } \\
\text { language } \\
\text { spoken at } \\
\text { home }\end{array}$ & $\begin{array}{l}\% \text { of students } \\
\text { with more } \\
\text { than } 10 \% \text { of } \\
\text { group } 1\end{array}$ & $\begin{array}{c}\% \text { of } \\
\text { schools } \\
\text { with more } \\
\text { than } 10 \% \text { of } \\
\text { group } 1\end{array}$ \\
\hline Austria & 0.09 & 0.12 & 0.10 & 0.26 & 0.30 \\
\hline Belgium & 0.07 & 0.18 & 0.05 & 0.24 & 0.27 \\
\hline Czech Republic & 0.02 & 0.07 & 0.01 & 0.05 & 0.07 \\
\hline Denmark & 0.04 & 0.10 & 0.04 & 0.12 & 0.11 \\
\hline Estonia & 0.02 & 0.21 & 0.00 & 0.02 & 0.03 \\
\hline Finland & 0.02 & 0.03 & 0.01 & 0.04 & 0.05 \\
\hline France & 0.04 & 0.21 & 0.05 & 0.14 & 0.15 \\
\hline Germany & 0.07 & 0.12 & 0.08 & 0.25 & 0.27 \\
\hline Greece & 0.08 & 0.07 & 0.04 & 0.20 & 0.36 \\
\hline Hungary & 0.02 & 0.02 & 0.01 & 0.03 & 0.04 \\
\hline Ireland & 0.08 & 0.12 & 0.02 & 0.32 & 0.32 \\
\hline Italy & 0.04 & 0.05 & 0.03 & 0.11 & 0.15 \\
\hline Latvia & 0.01 & 0.23 & 0.00 & 0.01 & 0.00 \\
\hline Lithuania & 0.01 & 0.09 & 0.00 & 0.03 & 0.03 \\
\hline Luxembourg & 0.18 & 0.34 & 0.21 & 0.74 & 0.65 \\
\hline Netherlands & 0.04 & 0.15 & 0.06 & 0.11 & 0.11 \\
\hline Portugal & 0.05 & 0.11 & 0.02 & 0.16 & 0.17 \\
\hline Romania & 0.00 & 0.00 & 0.01 & 0.00 & 0.00 \\
\hline Slovak Republic & 0.01 & 0.05 & 0.00 & 0.00 & 0.00 \\
\hline Slovenia & 0.02 & 0.16 & 0.06 & 0.05 & 0.06 \\
\hline Spain & 0.07 & 0.05 & 0.03 & 0.22 & 0.23 \\
\hline Sweden & 0.05 & 0.16 & 0.08 & 0.19 & 0.21 \\
\hline United Kingdom & 0.04 & 0.13 & 0.04 & 0.14 & 0.13 \\
\hline Europe & 0.05 & 0.11 & 0.04 & 0.15 & 0.17 \\
\hline
\end{tabular}

Group 1:

Students born abroad with at least one parent born abroad.

Group 2:

Students born in the country with at least one parent born abroad.

Other language:

The language spoken at home is not one of the official languages.

In Table 4 it can be seen that Catalonia is close to the average in immigration statistics, except that it has one of the greatest shares of schools with more than 10\% immigrants. 


\section{Table 4}

Immigration statistics (regions/countries sample)

$\begin{array}{lccccc} & \begin{array}{c}\text { Group } \\ 1\end{array} & \begin{array}{c}\text { Group } \\ 2\end{array} & \begin{array}{c}\text { Other } \\ \text { language } \\ \text { spoken at } \\ \text { home }\end{array} & \begin{array}{c}\text { \% of students } \\ \text { attending schools } \\ \text { with more } \\ \text { than } 10 \% \text { of } \\ \text { group } 1\end{array} & \begin{array}{c}\% \text { of } \\ \text { schools } \\ \text { with more } \\ \text { than } 10 \% \text { of } \\ \text { group 1 }\end{array} \\ \text { Flanders } & 0.04 & 0.11 & 0.03 & 0.13 & 0.15 \\ \text { Lombardy } & 0.06 & 0.05 & 0.04 & 0.22 & 0.29 \\ \text { Andalusia } & 0.03 & 0.03 & 0.02 & 0.09 & 0.08 \\ \text { Aragon } & 0.06 & 0.03 & 0.02 & 0.20 & 0.21 \\ \text { Asturias } & 0.03 & 0.05 & 0.05 & 0.09 & 0.12 \\ \text { Cantabria } & 0.05 & 0.04 & 0.01 & 0.19 & 0.23 \\ \text { Castile and Leon } & 0.04 & 0.02 & 0.01 & 0.11 & 0.12 \\ \text { Catalonia } & 0.08 & 0.06 & 0.04 & 0.28 & 0.30 \\ \text { Galicia } & 0.03 & 0.07 & 0.01 & 0.06 & 0.06 \\ \text { La Rioja } & 0.07 & 0.03 & 0.02 & 0.24 & 0.27 \\ \text { Navarre } & 0.08 & 0.04 & 0.02 & 0.33 & 0.33 \\ \text { Basque Country } & 0.04 & 0.03 & 0.01 & 0.09 & 0.13 \\ \text { Rest of Spain } & 0.10 & 0.05 & 0.03 & 0.31 & 0.32 \\ \text { All regions } & 0.06 & 0.06 & 0.03 & 0.20 & 0.21\end{array}$

Group 1:

Students born abroad with at least one parent born abroad.

Group 2:

Students born in the country with at least one parent born abroad.

Other language:

The language spoken at home is not one of the official languages.

\subsection{Average Effects of Family Background Variables and Aggregate PISA Scores}

We first study how teenagers (individual) PISA scores depend on the education levels of their parents and immigration status. Our goal is to estimate average effects across all European countries. Table 5 summarizes our findings on the effects of parental background variables. ${ }^{6}$ It can be seen that the effects associated with low parental education levels are large. For example, having an illiterate mother lowers the science score by more than 60 points, close to

\footnotetext{
${ }^{6}$ The underlying regression results are available at http://www.antoniociccone.com, Appendix Tables 1-3. OLS regressions based on the method suggested by PISA (2006), that is regression coefficients are the average of five separate regressions based on using the five plausible values for scores as the dependent variable, while standard errors are computed using 80 balanced repeated replications and 5 plausible values. Each table is organized in the same way. Column (1) contains the results of a regression of individual PISA scores on country dummies only. Hence, the results reflect countries' PISA scores. Column (2) adds controls for the education levels of fathers and mothers. The omitted category is upper-level secondary education; hence, all effects have to be read relative to this parental education level. Column (3) adds controls for immigration status, and column (4) a dummy that is unity if and only if the teenager attends a school with more than $10 \%$ immigrants.
} 
the difference between the Spanish and Finnish mean scores (Finland is the top performer in Europe). These results, combined with comparatively low Spanish parental education levels, therefore suggest that part of the low PISA score of Spain may be due to low parental education levels.

\section{Table 5}

Parental education effects (European sample)

$\begin{array}{lrrr} & \text { Science } & \text { Math } & \text { Reading } \\ \text { Father no degree } & -42.9 & -41.9 & -42.2 \\ \text { Father primary school } & -26.4 & -25.8 & -25.7 \\ \text { Father basic secondary } & -19.9 & -15.3 & -18.1 \\ \text { Father college } & 16.0 & 15.7 & 12.0 \\ \text { Mother no degree } & -62.6 & -53.9 & -61.5 \\ \text { Mother primary school } & -40.2 & -37.3 & -43.4 \\ \text { Mother basic secondary } & -25.4 & -21.1 & -28.5 \\ \text { Mother college } & 10.4 & 11.7 & 6.6 \\ \text { Note: Full regression results can be found in the Appendix. } & \\ \text { Deviations from the average. } & & & \end{array}$

Table 6 summarizes our findings on the effects of immigration status on PISA scores (these effects are conditional on parental education levels). The effects are also quite large. For example, teenagers born abroad with one parent born abroad (group 1) score 28 points lower in science, and the score falls by a further 24 points if families do not speak an official language at home. But because European countries appear quite similar when it comes to immigrants, we expect immigration status variables to contribute less to cross-country PISA differences. The table also shows that teenagers in schools with more than $10 \%$ immigrants score more than 30 points lower in science, math, and reading. It seems very unlikely that this effect is causal as a greater concentration of immigrants at a school will probably lead some of the parents most concerned about education to take their children elsewhere. ${ }^{7}$ But the effect is likely to be an upper bound on the causal effect and therefore useful for our analysis.

\footnotetext{
${ }^{7}$ Betts, J. R. and R. W. Fairlie (2003).
} 


\section{Table 6}

Immigration status effects (European sample)

$\begin{array}{lcrc} & \text { Science } & \text { Math } & \text { Reading } \\ \text { Group 1 } & -28.2 & -22.0 & -22.1 \\ \text { Group 2 } & -10.4 & -9.2 & -4.7 \\ \text { Other language } & -24.3 & -19.3 & -21.8 \\ \text { In a school with } & -31.0 & -32.2 & -34.1 \\ \text { group 1 > 10\% } & & & \end{array}$

Group 1: Student born abroad with at least one parent born abroad.

Group 2: Student native with at least one parent born abroad.

Other language: language spoken at home is not official in the country.

Deviations from the average.

\section{Counterfactual Analysis of Aggregate PISA Scores}

We will now ask how Catalonia's and Spain's scores would have compared to other countries and regions if all had the same parental education and immigration levels. For robustness we will do the counterfactual analysis in two different ways. Our first approach adjusts the unconditional PISA scores using the average effects of parental education levels and immigration status in the sample. ${ }^{8}$ Our second approach makes the adjustment based on country and region specific effects of parental education and immigration.

\subsection{Counterfactual Analysis of Aggregate PISA Scores Based on Average Effects}

Figure 1 illustrates how Spanish PISA scores in science, math, and reading would compare with other European countries if all had the same parental education levels. All figures are constructed in the same way. On the vertical axis we have put the difference between countries' (unconditional) PISA scores and the European average. On the horizontal axis, we have put the same difference after controlling for parental education. Countries that lie below the 45 degree line improve relative to the average when controlling for parental education; countries above do worse. The horizontal difference from the 45 degree line is a measure of how much the country improves (worsens) when parental education levels are accounted for. ${ }^{9}$

\footnotetext{
${ }^{8}$ This approach is based directly on the regressions in Appendix Tables 1-6.

${ }^{9}$ The numerical values are given in Appendix Tables 7, 10, and 13.
} 


\section{Figure 1}

PISA versus adjusted PISA scores (European sample)
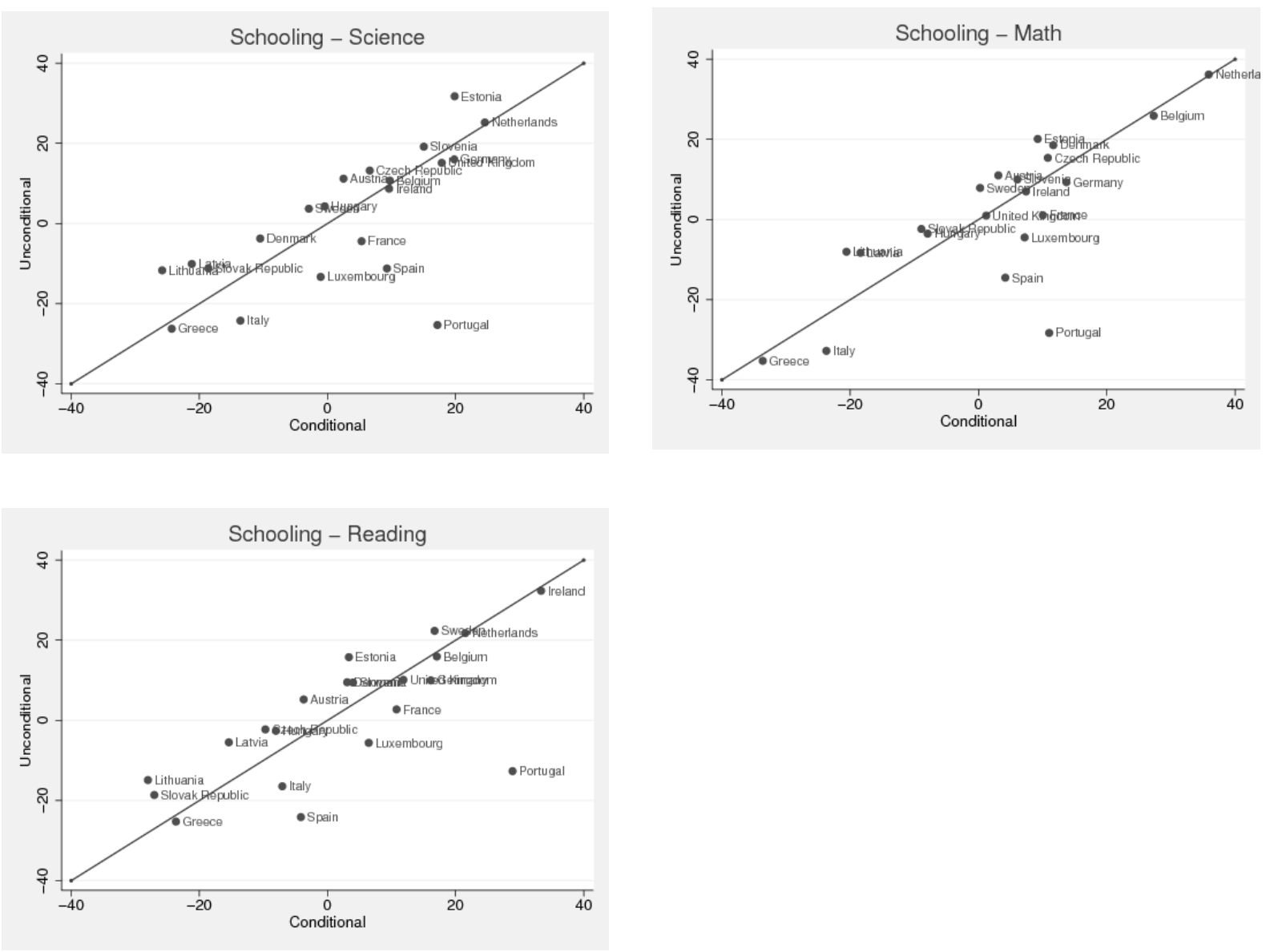

Note: Regression method. Deviations from the average. Finland and Romania omitted from the graph.

The picture that emerges is quite clear. Spain is one of the two or three countries improving most when parental education is accounted for (only Portugal and sometimes Luxembourg show bigger improvements). For example, in science Spain goes from more than 11 points below average to more than 9 points above average; in math, from more than 14 points below average to more than 4 points above average; and in reading, from more than 24 points below average to 4 points below average. What these results indicate is that, if we compare teenagers whose parents have the same education levels across European countries, Spain is somewhat above average in science and math, and just below average in reading.

Figure 2 repeats the analysis controlling for parental education levels and immigration status. ${ }^{10}$ This changes the overall picture little. For example, controlling for parental education and immigration status, Spain lies 7.4 points above the average, compared to 9.3 points when controlling for parental education only. For math, the comparison is 2.5 above average vis-àvis 4.2 points above average. And for reading 5.5 points below average compared to 4.2 below

\footnotetext{
${ }^{10}$ The corresponding numerical values are given in Appendix Tables 8, 11, and 14.
} 
average. Overall, accounting for immigration status does not much change the position of Spain relative to the average European country.

\section{Figure 2}

PISA versus adjusted PISA Scores (European sample)
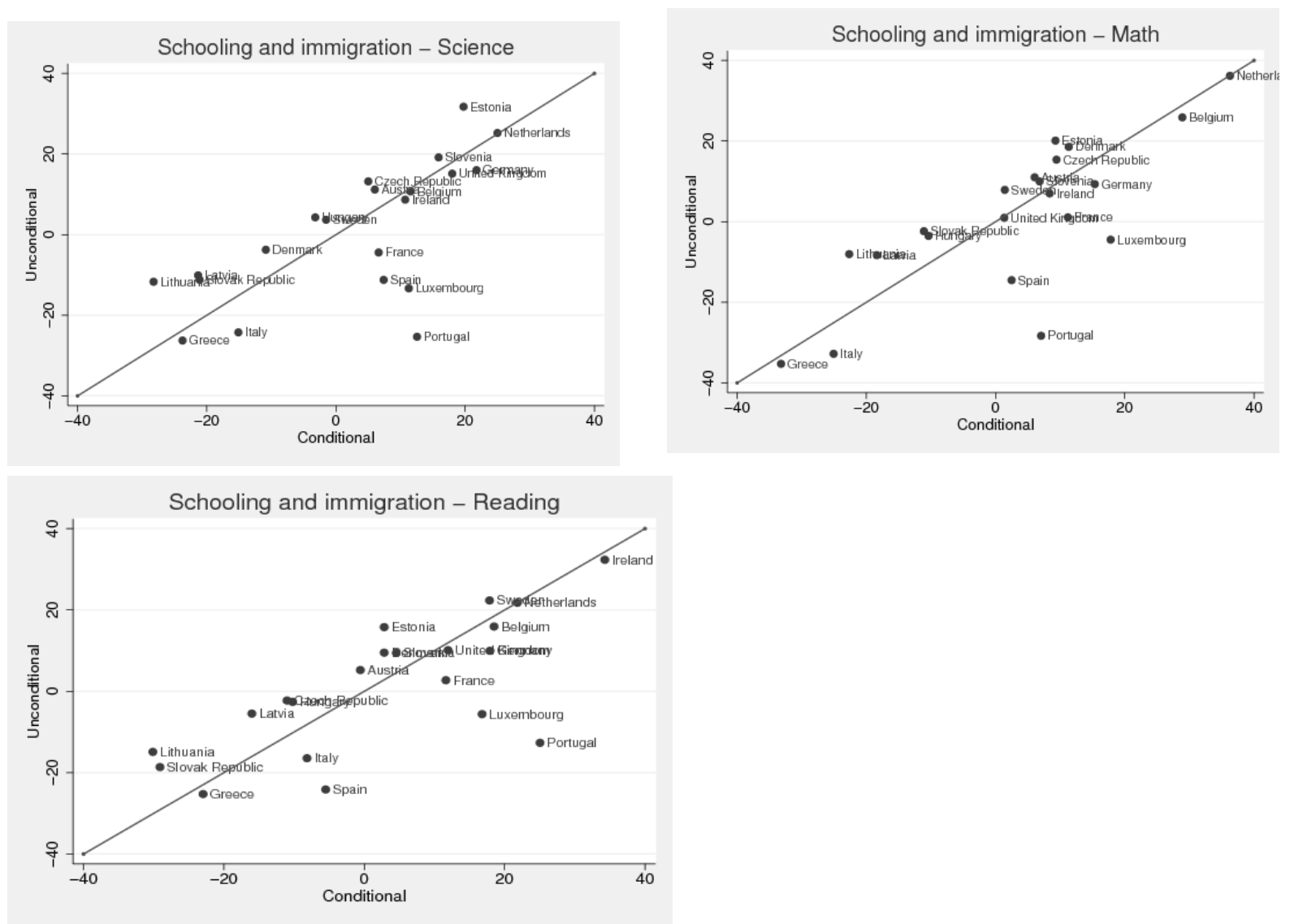

Note: Regression method. Deviations from the average. Finland and Romania omitted from the graph.

Figure 3 also accounts for schools with more than 10\% immigrants. ${ }^{11}$ Again, the results change little. The main conclusion from Figures 1-3 is therefore quite clear. While low education levels of parents did play a significant role-results in science and math go from clearly below average to somewhat above average when parental education are accounted for-immigration status is not a significant factor behind Spain's comparatively poor PISA performance.

\footnotetext{
${ }^{11}$ The corresponding numerical values are given in Appendix Tables 9, 12, and 15.
} 


\section{Figure 3}

PISA versus adjusted PISA Scores (European sample)
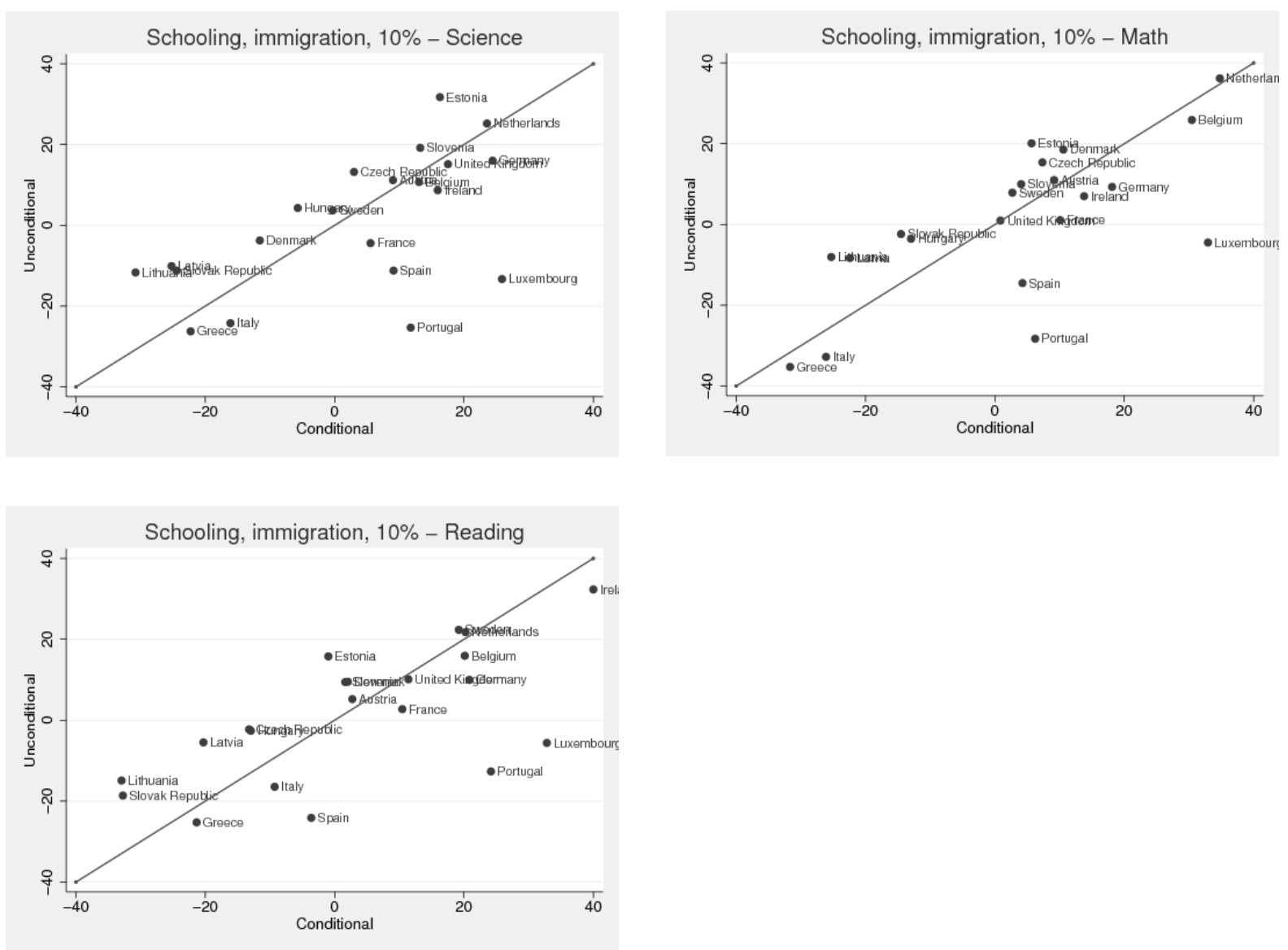

Note: Regression method. Deviations from the average. Finland and Romania omitted from the graph.

Table 7 compares Spain with Finland, the Netherlands, Germany, Denmark, Italy, and Portugal. Consider the results for science, for example. It is evident that low Spanish parental education levels account for a sizable part of the gaps between Spain on the one hand and Finland, the Netherlands, and Germany on the other hand. The (small) gap between Spain and Denmark actually changes sign and turns into a sizable advantage for Spain once one controls for parental education. Similarly, the lead with respect to Italy widens. Spain only worsens compared to Portugal, which has even lower parental education levels (see Table 1).

Table 7 also analyzes the PISA math and reading scores. In the case of the math scores, the gap between Spain and Finland and between Spain and the Netherlands halves once parental education is accounted for. The gap with Germany diminishes by around 15 points and the gap with Denmark by around 25 points. The results for reading are similar. Tables 7 also shows that Spain's relative position changes little when immigration status is accounted for, especially compared to the changes when accounting for parental education levels. 


\section{Table 7}

PISA and adjusted PISA scores in Spain compared with selected European countries

\begin{tabular}{|c|c|c|c|c|}
\hline & $\begin{array}{c}\text { Unconditional } \\
\text { average }\end{array}$ & $\begin{array}{l}\text { Parental } \\
\text { education } \\
\text { controls } \\
\text { only }\end{array}$ & $\begin{array}{c}\text { Parental } \\
\text { education } \\
\text { and immigration } \\
\text { controls }\end{array}$ & $\begin{array}{l}\text { Parental } \\
\text { education } \\
\text { immigration } \\
\text { and }>10 \% \\
\text { controls }\end{array}$ \\
\hline \multicolumn{5}{|l|}{ Science } \\
\hline Finland - Spain & 74.9 & 42.0 & 40.4 & 36.4 \\
\hline Netherlands - Spain & 36.5 & 15.3 & 17.6 & 14.5 \\
\hline Germany - Spain & 27.2 & 10.5 & 14.4 & 15.3 \\
\hline Denmark - Spain & 7.5 & -19.8 & -18.3 & -20.7 \\
\hline Italy - Spain & -13.0 & -22.9 & -22.5 & -25.2 \\
\hline Portugal - Spain & -13.1 & 7.9 & 5.1 & 2.7 \\
\hline \multicolumn{5}{|l|}{ Math } \\
\hline Finland - Spain & 68.4 & 38.0 & 36.7 & 32.6 \\
\hline Netherlands - Spain & 50.7 & 31.7 & 33.8 & 30.5 \\
\hline Germany - Spain & 23.8 & 9.5 & 12.8 & 13.8 \\
\hline Denmark - Spain & 33.0 & 7.4 & 8.8 & 6.3 \\
\hline Italy - Spain & -18.3 & -27.9 & -27.6 & -30.4 \\
\hline Portugal - Spain & -13.8 & 6.8 & 4.5 & 1.9 \\
\hline \multicolumn{5}{|l|}{ Reading } \\
\hline Finland - Spain & 86.1 & 55.5 & 54.1 & 49.7 \\
\hline Netherlands - Spain & 45.9 & 25.7 & 27.3 & 23.8 \\
\hline Germany - Spain & 34.1 & 20.3 & 23.4 & 24.4 \\
\hline Denmark - Spain & 33.7 & 7.3 & 8.3 & 5.6 \\
\hline Italy - Spain & 7.7 & -2.9 & -2.7 & -5.7 \\
\hline Portugal - Spain & 11.5 & 33.1 & 30.5 & 27.8 \\
\hline
\end{tabular}

Tables 8-9 summarize the effects of parental education and immigration status on individual PISA scores in our mixed regions/country sample. ${ }^{12}$ The results for parental education levels in Table 8 are qualitatively very similar to the European country sample. But the size of the effects tends to be somewhat smaller. For example, now a mother with a primary school degree only is associated with a 30 point lower score, while in the European sample the effect was 40 points. Table 9 contains the results for immigration status, which are also qualitatively similar to those we obtained in the European sample. For example, teenagers born abroad with one parent born abroad (group 1) score 47 points lower in science; if only the parents were born abroad the effect is 12 points. These estimates are somewhat larger than for the European sample (especially for group 1). On the other hand, the effect of not speaking an official language at home and of being in a school with more than $10 \%$ immigrants is somewhat smaller than in the European sample.

\footnotetext{
12 Taken from Appendix Tables 4-6.
} 


\section{Table 8}

Parental education effects (regions/countries sample)

\begin{tabular}{|c|c|c|c|}
\hline & Science & Math & Reading \\
\hline Father no degree & -26.1 & -29.4 & -28.3 \\
\hline $\begin{array}{l}\text { Father primary } \\
\text { school }\end{array}$ & -19.0 & -18.0 & -19.4 \\
\hline $\begin{array}{l}\text { Father basic } \\
\text { secondary }\end{array}$ & -6.6 & -4.0 & -2.1 \\
\hline Father college & 17.6 & 17.3 & 11.3 \\
\hline Mother no degree & -52.1 & -40.0 & -44.3 \\
\hline $\begin{array}{l}\text { Mother primary } \\
\text { school }\end{array}$ & -30.8 & -27.6 & -31.2 \\
\hline $\begin{array}{l}\text { Mother basic } \\
\text { secondary }\end{array}$ & -9.7 & -5.9 & -7.6 \\
\hline Mother college & 13.1 & 10.9 & 8.6 \\
\hline
\end{tabular}

\section{Table 9}

Immigration status effect (regions/countries sample)

$\begin{array}{lccc} & \text { Science } & \text { Math } & \text { Reading } \\ \text { Group 1 } & -47.0 & -44.3 & -38.5 \\ \text { Group 2 } & -12.9 & -15.5 & -12.3 \\ \text { Other language } & -14.3 & -3.9 & -19.5 \\ \text { In a school with } & -21.1 & -23.2 & -30.5 \\ \text { group 1 > 10\%. } & & \\ \text { Group 1: Student born abroad with at least one parent born abroad. } \\ \text { Group 2: Student native with at least one parent born abroad. } \\ \text { Other language: language spoken at home is not official in the country. } \\ \text { Deviations from the average. }\end{array}$

Figure 4 plots the unconditional difference of each country/region's score with the average on the vertical axis against the difference accounting for parental education levels. ${ }^{13}$ Catalonia is very close to the 45 degree line in all cases, which indicates that parental education levels cannot explain its performance relative to the average. Only Andalusia experiences a substantial improvement.

\footnotetext{
${ }^{13}$ The corresponding numerical values are given in Appendix Tables 16, 19, and 22.
} 


\section{Figure 4}

PISA versus adjusted PISA scores (regions/countries sample)
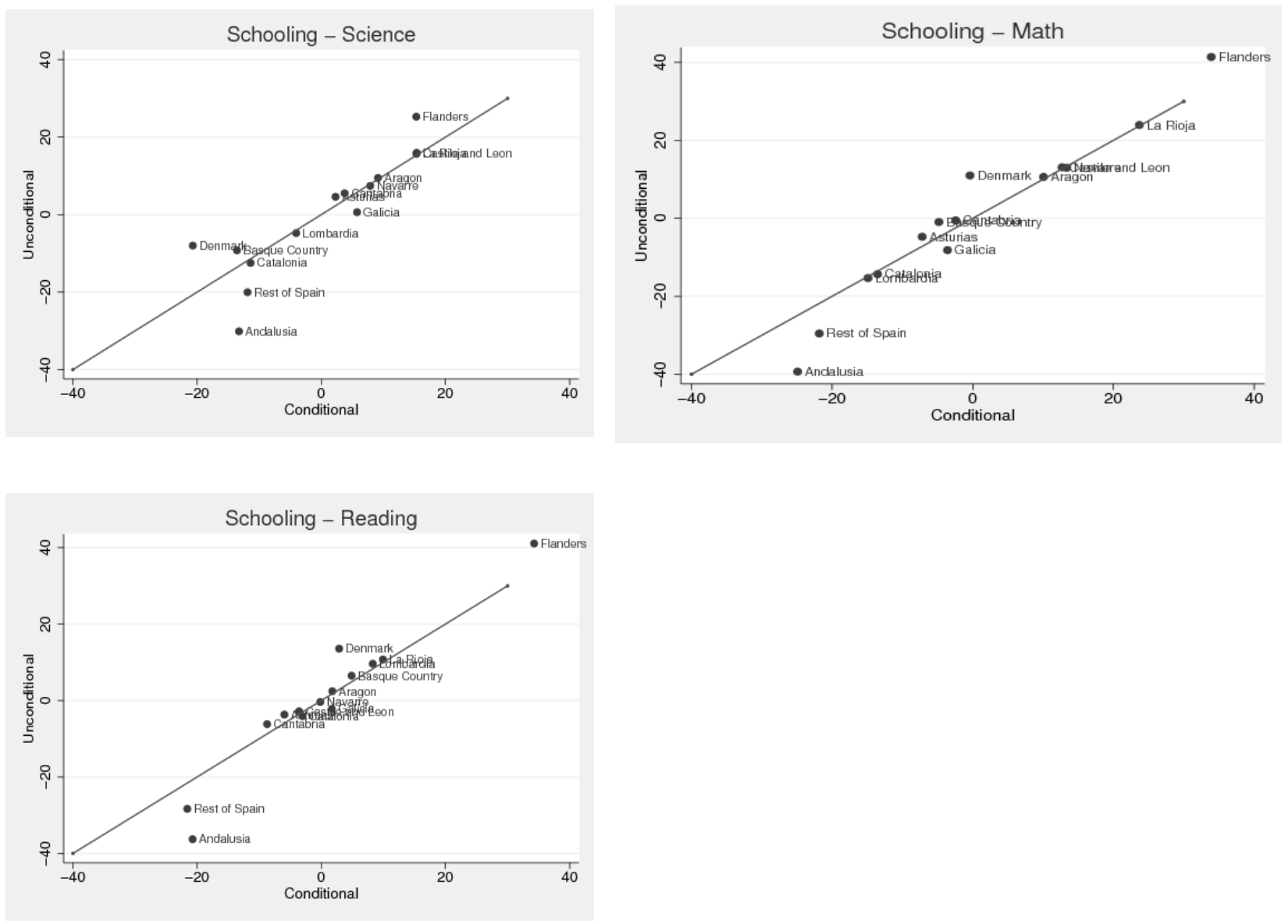

Note: Regression method. Deviations from the average.

Figure 5 adds immigration status controls. ${ }^{14}$ Catalonia continues to be very close to the 45 degree line in all cases, which implies that immigration status variables also fail to explain its performance relative to the average.

\footnotetext{
${ }^{14}$ The corresponding numerical values are given in Appendix Tables 17, 20, and 23.
} 


\section{Figure 5}

PISA versus adjusted PISA scores (regions/countries sample)
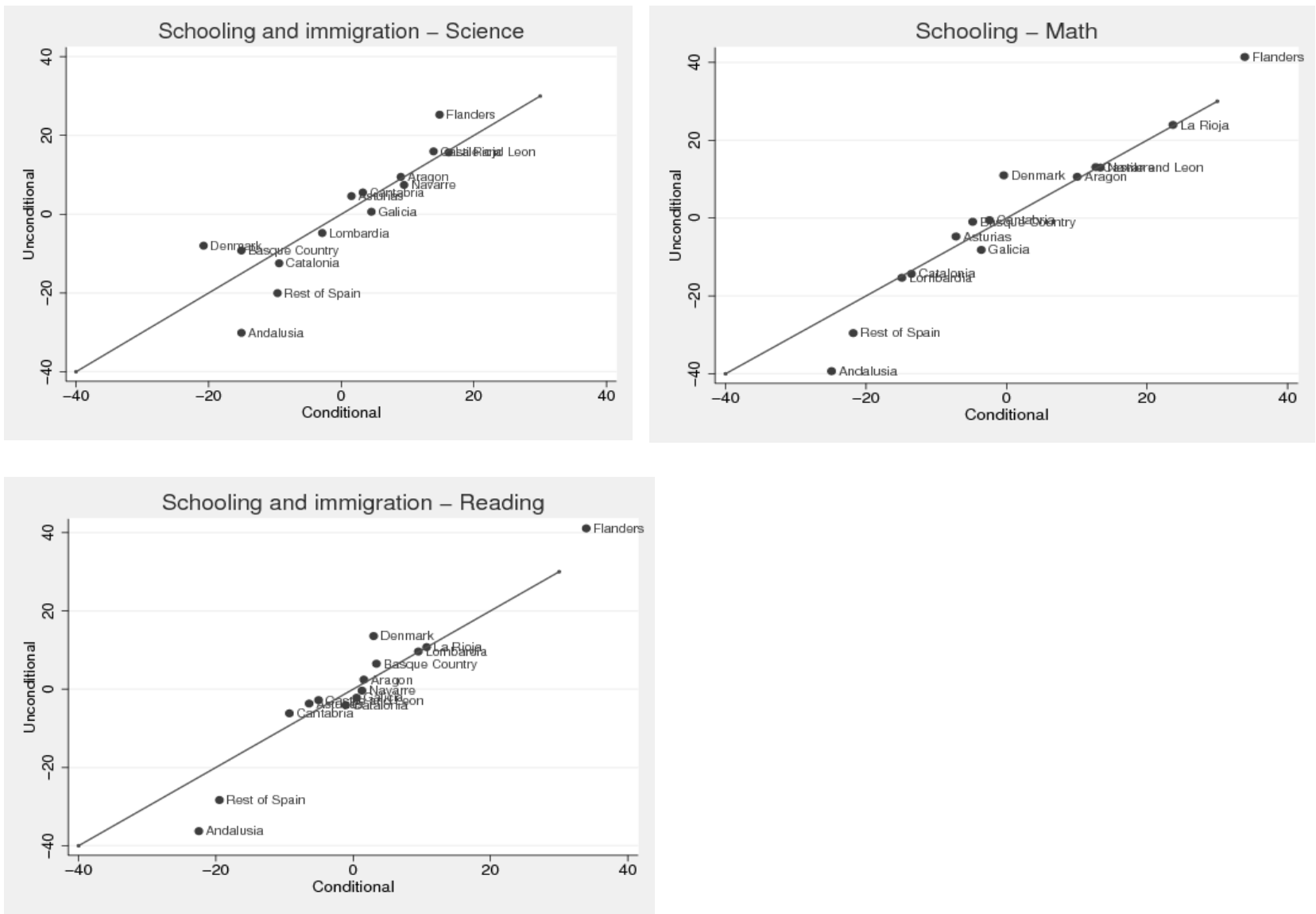

Note: Regression method. Deviations from the average.

Finally, in Figure 6, we add controls for the share of schools with more than $10 \%$ immigrants. ${ }^{15}$ That is, we ask how each country/region would compare to the average if it had the same parental education levels and immigration shares (including schools with more than 10\% immigrants).

\footnotetext{
${ }^{15}$ The corresponding numerical values are given in Appendix Tables 18, 21, and 24.
} 


\section{Figure 6}

PISA versus adjusted PISA scores (regions/countries sample)
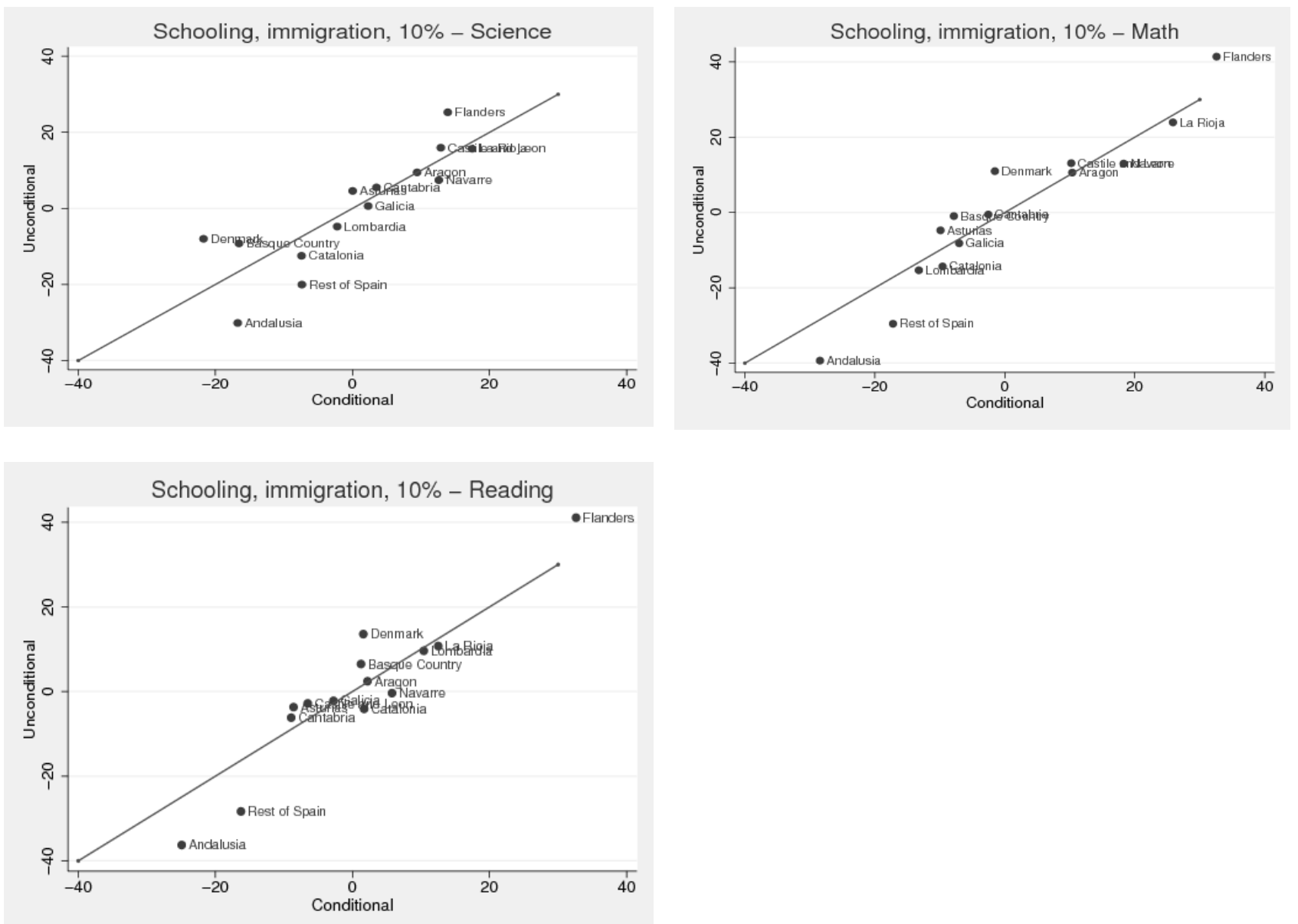

Note: Regression method. Deviations from the average.

Now Catalonia moves somewhat to the right of the 45 degree line, which indicates that immigrant concentration explains some of the gap with the average in other countries/regions. But it explains very little. For example, controlling for parental schooling, Catalonia is 11.4 points below the average in science, and the gap shrinks to 7.5 when we control for immigration status and immigrant concentration. For the math and the reading score the results are very similar. This result is easily explained with the help of Tables 4 and 6 . Compared to the average, Catalonia has about 10\% more children in schools with more than 10\% immigrants. Given that these children score about 25 points worse in the PISA tests, this can account for a 2.5 point gap with the average (10\%*25 points). Moreover, Catalonia has $8 \%$ teenagers born abroad with a parent born abroad while the average across the country/region sample is $6 \%$. These teenagers do about 50 points worse and therefore lower the Catalan average by 1 point relative to the average (2\%*50 points). The sum of these two effects ( 3.5 points) gets us very close to the part of the performance gap that can be explained by immigration shares and immigrant concentration at some schools.

Table 10 compares the unconditional and adjusted PISA scores of Catalonia with Flanders, Denmark, Lombardy, La Rioja, and Castile and Leon (Flanders is the top performer in this group). Unconditionally, Catalonia is behind in almost all comparisons, with the exception of the math score where it does slightly better than Lombardy. Generally speaking, educational 
background helps in explaining around 8-12 points of the PISA gap with Flanders and Denmark. It is interesting to note that Catalonia is considerably behind La Rioja as well as Castile and Leon in science and math (the gap is almost 30 points in science and between 30 and 40 points in math). These gaps change very little when we control for parental education levels. Note also that in science, both La Rioja and Castile and Leon do as well as Flanders when parental education levels are accounted for. The results in Table 10 also show that adding immigration status and immigration concentration controls changes the results for Catalonia little compared to the other regions and countries.

The results of Figures 5-6 and Table 10 are quite clear. Parental education levels and immigration explain little of the gap between Catalonia and the average of the countries and regions considered. If we focus on pairwise comparisons between Catalonia and regions or countries outside Spain, a part of the gap can be explained by parental education but little by immigration. When we consider comparisons between Catalonia and the Spanish regions that did best (La Rioja and Castile and Leon), we find that little of the sizable gap in science and math can be explained by parental education or immigration variables.

\section{Table 10}

PISA and adjusted PISA scores in Catalonia compared with selected European regions/countries

\begin{tabular}{|c|c|c|c|c|}
\hline & $\begin{array}{l}\text { Unconditional } \\
\text { average }\end{array}$ & $\begin{array}{l}\text { Parental } \\
\text { education } \\
\text { controls } \\
\text { only }\end{array}$ & $\begin{array}{l}\text { Parental } \\
\text { education } \\
\text { and } \\
\text { immigration } \\
\text { controls }\end{array}$ & $\begin{array}{c}\text { Parental } \\
\text { education } \\
\text { immigration } \\
\text { and }>10 \% \\
\text { controls }\end{array}$ \\
\hline \multicolumn{5}{|l|}{ Science } \\
\hline Flanders - Catalonia & 37.8 & 26.7 & 24.2 & 21.3 \\
\hline Denmark - Catalonia & 4.5 & -9.3 & -11.4 & -14.3 \\
\hline Lombardy - Catalonia & 7.7 & 7.4 & 6.5 & 5.2 \\
\hline La Rioja - Catalonia & 28.2 & 26.7 & 25.6 & 24.9 \\
\hline Castile and Leon - Catalonia & 28.4 & 26.8 & 23.3 & 20.3 \\
\hline \multicolumn{5}{|l|}{ Math } \\
\hline Flanders - Catalonia & 55.7 & 47.4 & 45.3 & 42.2 \\
\hline Denmark - Catalonia & 25.3 & 13.1 & 11.2 & 8.1 \\
\hline Lombardy - Catalonia & -1 & -1.4 & -2.2 & -3.6 \\
\hline La Rioja - Catalonia & 38.3 & 37.2 & 36.2 & 35.5 \\
\hline Castile and Leon - Catalonia & 27.4 & 26.2 & 23 & 19.8 \\
\hline \multicolumn{5}{|l|}{ Reading } \\
\hline Flanders - Catalonia & 45.2 & 37.3 & 32.8 & 30.9 \\
\hline Denmark - Catalonia & 17.7 & 5.9 & 1.9 & -0.1 \\
\hline Lombardy - Catalonia & 13.7 & 11.3 & 8.4 & 8.7 \\
\hline La Rioja - Catalonia & 14.4 & 12.9 & 9.6 & 10.8 \\
\hline Castile and Leon - Catalonia & 1.3 & -0.6 & -6.1 & -8.2 \\
\hline
\end{tabular}

$>10 \%$ control: dummy for students attending schools with more than $10 \%$ immigration 


\subsection{Counterfactual Analysis of Aggregate PISA Scores Based on Heterogeneous Effects}

Our second approach is almost as straightforward as our first. We first estimate the effects of parental education levels, immigration status, and the dummy for schools with more than $10 \%$ immigration for each country/region separately. Based on these regressions, we predict the score in each country and region if it had the Catalan (Spanish) parental education levels, immigration levels, and concentration of immigrants at a subset of schools. For Catalonia (Spain), this prediction simply yields the average Catalan (Spanish) score. For all other countries and regions it yields how it would have performed at the Catalan (Spanish) composition, given the actual performance of each student group in the country or region (our previous approach used the average performance of the group in the entire sample to make this adjustment). This approach is often referred to as shift-share analysis.

Figure 7 contains the results for science, math, and reading in the European sample when we adjust for parental education levels only. ${ }^{16}$ It can be seen that Spain is always among the three countries that improve most (the improvement is equal to the horizontal distance from the 45 degree line). Moreover, Spain moves from below the average to above the average in all three test categories. The situation changes little when we also control for immigration status in Figure 8 and immigrant concentration in Figure 9. ${ }^{17}$

\section{Figure 7}

PISA versus adjusted PISA scores (European sample)
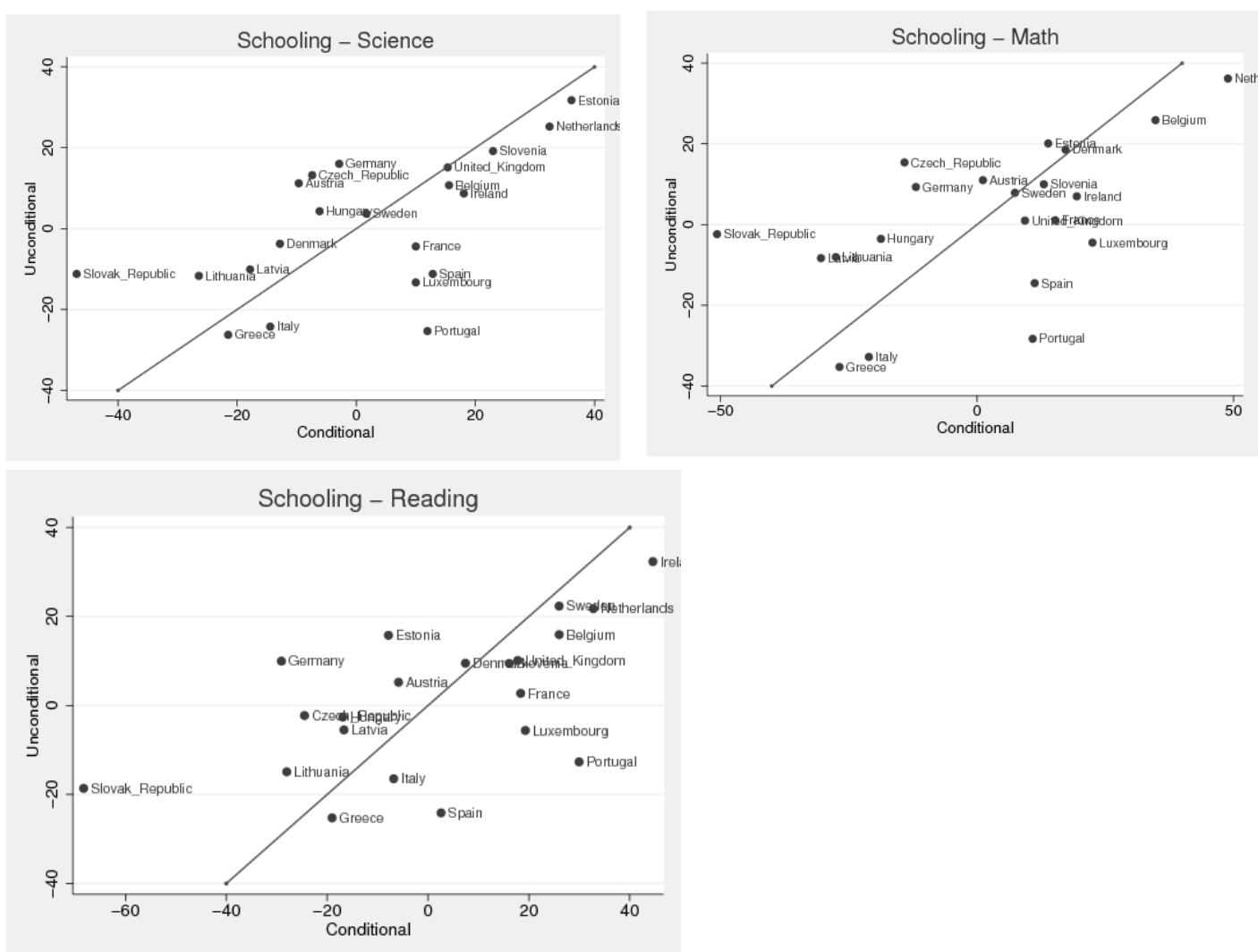

Note: Shift-share method. Deviations from the mean.

Finland and Romania omitted from the graph.

\footnotetext{
${ }^{16}$ The corresponding numerical values are given in Appendix Tables 25, 28, and 31.

${ }^{17}$ The corresponding numerical values are given in Appendix Tables 26, 29, 32 and 27, 30, 33 respectively.
} 


\section{Figure 9}

PISA versus adjusted PISA scores (European sample)
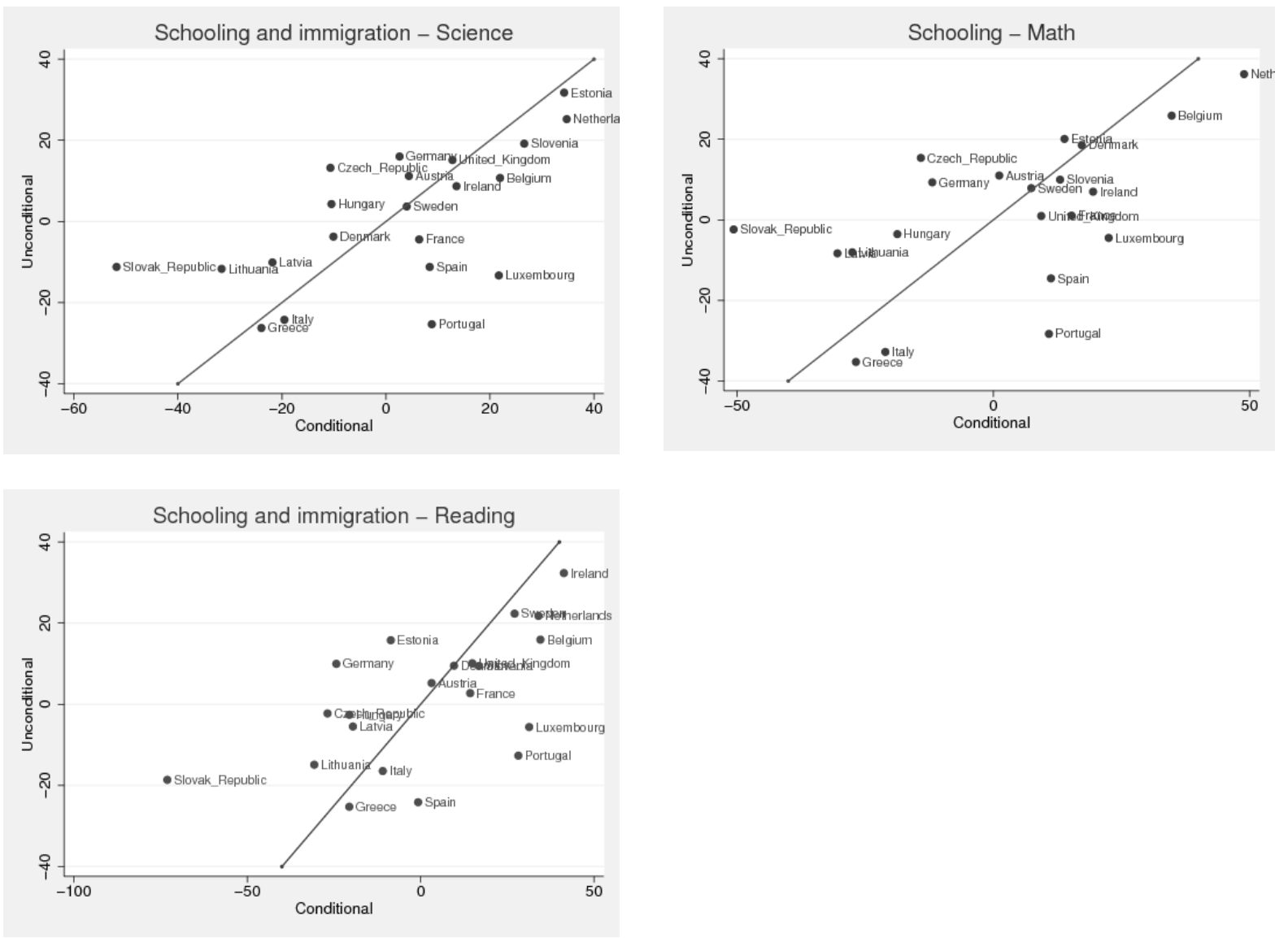

Note: Shift-share method. Deviations from the mean.

Finland and Romania omitted from the graph.

The results for Catalonia in the mixed region/country sample are in Figures 10-12. In Figure 10 - which looks at science, math, and reading results controlling for parental schooling only - it can be seen that Catalonia moves at most a few points away from the 45 degree line. Hence, the Catalan gap with average performance in the sample changes little when we control for parental education. The same is true when we control for immigration status and concentration at some schools (Figure 11 and Figure 12 respectively). 


\section{Figure 10}

PISA versus adjusted PISA scores (regions/countries sample)
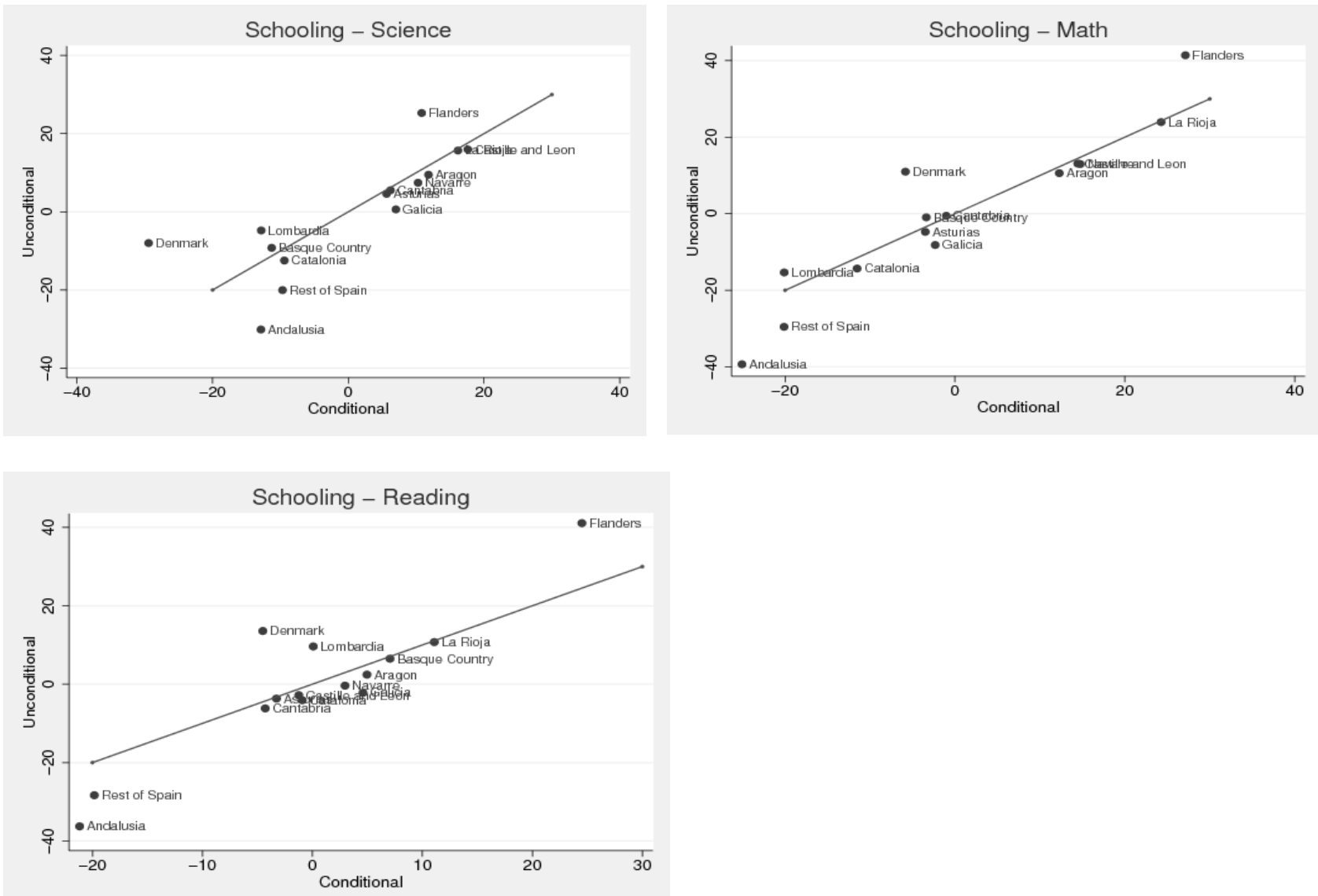

Note: Shift-share method. Deviations from the average. 


\section{Figure 11}

PISA versus adjusted PISA scores (regions/countries sample)
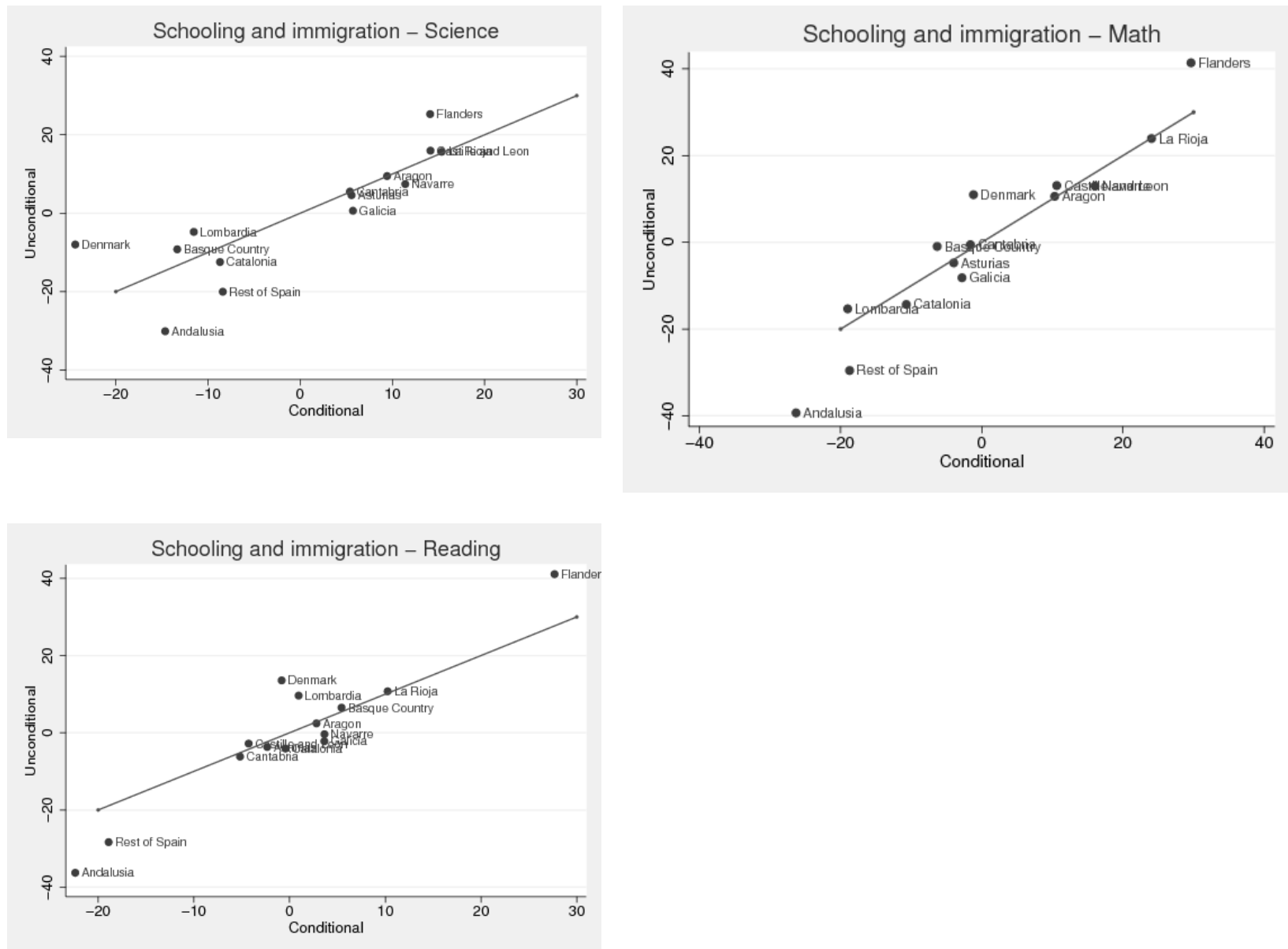

Note: Shift-share method. Deviations from the average. 


\section{Figure 12}

PISA versus adjusted PISA scores (regions/countries sample)
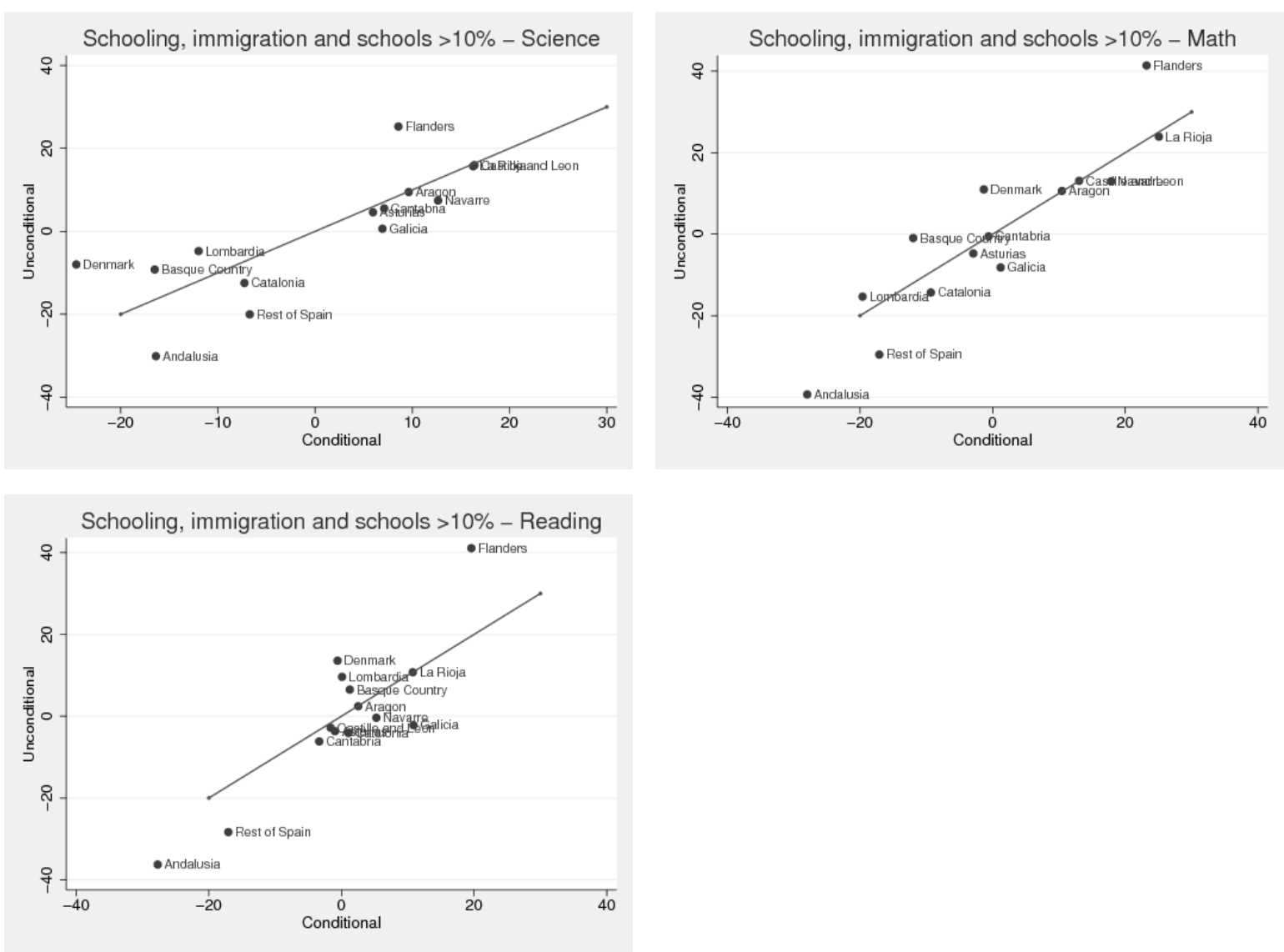

Note: Shift-share method. Deviations from the average.

\subsection{Comparing the Two Counterfactual Methods}

Figures 13 and 14 compare the two methodologies to calculate counterfactual PISA scores. On the vertical axis, we measure the distance from the average in science, math, and reading using the regressions method (our first approach). On the horizontal axis we measure the same distance using the shift-share method (our second approach). There are a total of nine points in each figure because we undertake three counterfactual experiments: controlling for parental schooling only, adding immigration status, and adding the concentration of immigrants at some schools. In Figure 13 it can be seen that Spain does better compared to the average using the shift-share approach than the regression approach (all points lie to the right of the 45 degree line). But the results of the two methods are quite similar when schooling and immigration is accounted for. Figure 14 shows that both methods yield very similar results for Catalonia. 


\section{Figure 13}

Comparison of methods on Spain scores (European sample)

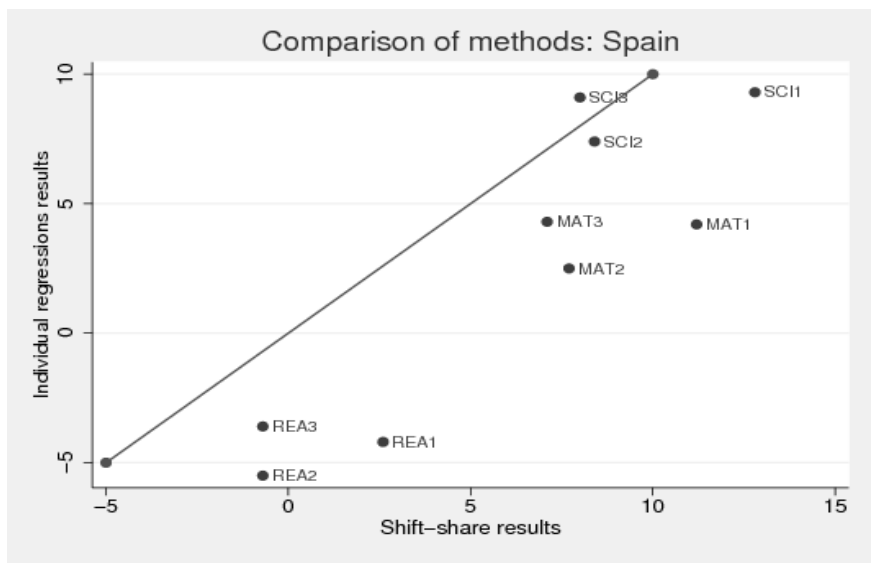

SCl: Science, MAT: Math, REA: Reading. 1: Schooling controls, 2: Schooling and immigration controls, 3: Schooling, immigration and dummy for students attending more than $10 \%$

\section{Figure 14}

Comparison of methods on Catalan scores (regions/countries sample)

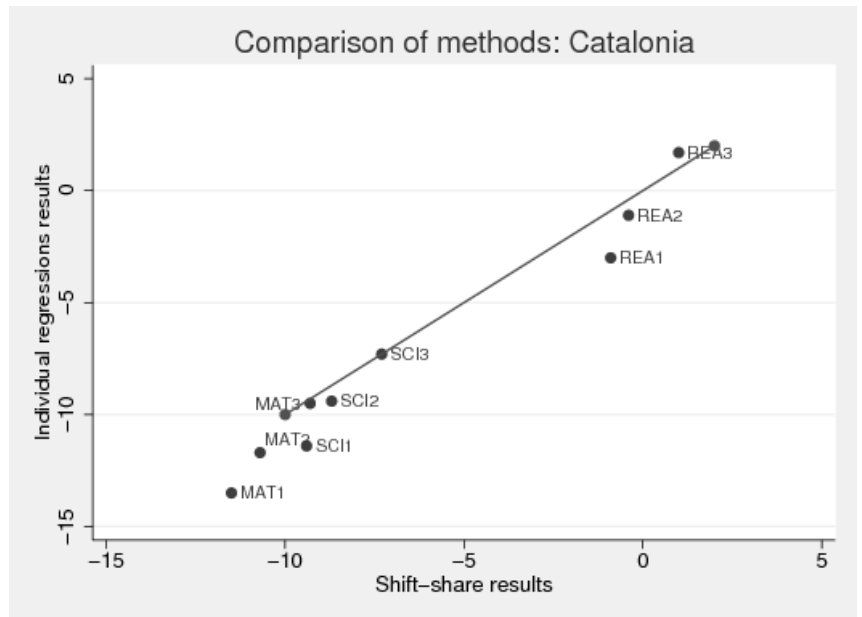

SCl: Science, MAT: Math, REA: Reading. 1: Schooling controls, 2: Schooling and immigration controls, 3: Schooling, immigration and dummy for students attending more than $10 \%$.

\section{Convergence in Parental Education Levels and the Future of PISA Scores}

Controlling for education levels, Spanish PISA scores in science and math are more than ten points above the European average. It is therefore natural to ask whether Spanish PISA scores will rise above the European average as parental education levels in Spain converge to the European Union average. Unfortunately, this is not to be expected. Table 11 contains the average performance in science of native teenagers who attend schools with less than $10 \%$ 
immigrants and have both parents with lower secondary school, upper secondary school, or college education. Performance is relative to the European average of teenagers with the same family background characteristics attending schools with less than 10\% immigration. It can be seen that teenagers with parents who only completed lower secondary school outperform the European average by almost 13 points. But teenagers with upper secondary school educated parents and college educated do not outperform the European average. Spain can therefore not be expected to rise above the European average of the PISA science scores as parental education levels increase.

\section{Table 11}

Average science scores of native students at schools with less than $10 \%$ immigrant students (European sample)

$\begin{array}{lcccr} & \text { Unconditional } & \text { Advanced } & \text { Low } & \\ \text { secondary } & \text { secondary } & \text { College } \\ \text { Austria } & 11.2 & 19.3 & 7.2 & 1.7 \\ \text { Belgium } & 10.7 & 18.0 & 35.7 & 20.7 \\ \text { Czech Republic } & 13.2 & 9.7 & -5.3 & 10.8 \\ \text { Denmark } & -3.7 & -15.1 & -13.1 & -5.9 \\ \text { Estonia } & 31.8 & 23.7 & 24.1 & 22.2 \\ \text { Finland } & 63.7 & 38.1 & 68.7 & 36.7 \\ \text { France } & -4.4 & 7.7 & 1.2 & 12.8 \\ \text { Germany } & 16.0 & 36.6 & 17.0 & 40.8 \\ \text { Greece } & -26.3 & -21.8 & -30.0 & -24.4 \\ \text { Hungary } & 4.3 & -7.7 & -42.3 & 19.5 \\ \text { Ireland } & 8.7 & -3.1 & 10.0 & 5.1 \\ \text { Italy } & -24.2 & -11.6 & -16.1 & -35.3 \\ \text { Latvia } & -10.1 & -23.5 & -34.5 & -28.9 \\ \text { Lithuania } & -11.7 & -38.9 & -33.2 & -23.0 \\ \text { Luxembourg } & -13.3 & 39.2 & 102.9 & 4.2 \\ \text { Netherlands } & 25.2 & 19.6 & 47.3 & 27.5 \\ \text { Portugal } & -25.3 & -7.1 & 19.2 & -14.1 \\ \text { Romania } & -81.3 & -85.5 & -104.8 & 105.5 \\ \text { Slovak Republic } & -11.2 & -24.8 & -91.1 & 4.4 \\ \text { Slovenia } & 19.2 & 8.1 & -10.1 & 39.2 \\ \text { Spain } & -11.2 & -5.2 & 12.9 & -0.1 \\ \text { Sweden } & 3.7 & 6.5 & 16.1 & -18.3 \\ \text { United Kingdom } & 15.1 & 17.6 & 18.2 & 9.9\end{array}$

Unconditional: average overall score. Advanced secondary: student is native with both parents with advanced secondary education (reference group for the regressions). Low secondary: student is native with both parents with lower secondary education. College: student is native with both parents with college education.

Deviations from the average. 
Table 12 repeats the analysis for math scores and Table 13 for the reading scores.

\section{Table 12}

Average math scores of native students at schools with less than 10\% immigrant students (European sample)

\begin{tabular}{|c|c|c|c|c|}
\hline & Unconditional & $\begin{array}{l}\text { Advanced } \\
\text { secondary }\end{array}$ & $\begin{array}{c}\text { Low } \\
\text { secondary }\end{array}$ & College \\
\hline Austria & 11.0 & 18.9 & 7.1 & 0.2 \\
\hline Belgium & 25.9 & 39.9 & 50.6 & 39.7 \\
\hline Czech Republic & 15.4 & 13.1 & -26.9 & 19.1 \\
\hline Denmark & 18.6 & 8.8 & 10.0 & 10.2 \\
\hline Estonia & 20.1 & 12.3 & -0.7 & 11.8 \\
\hline Finland & 53.9 & 33.1 & 56.4 & 28.2 \\
\hline France & 1.1 & 15.3 & 11.3 & 12.5 \\
\hline Germany & 9.3 & 27.9 & 16.1 & 35.9 \\
\hline Greece & 35.3 & -32.8 & -47.1 & -31.6 \\
\hline Hungary & -3.5 & -16.6 & -52.6 & 17.8 \\
\hline Ireland & 7.0 & -3.1 & 9.6 & -0.5 \\
\hline Italy & 32.8 & -23.8 & -20.6 & -43.1 \\
\hline Latvia & -8.3 & -24.5 & -15.3 & -23.2 \\
\hline Lithuania & -8.0 & -38.7 & -30.9 & -17.1 \\
\hline Luxembourg & -4.5 & 48.4 & 117.3 & 10.4 \\
\hline Netherlands & $\begin{array}{r}36.2 \\
-\end{array}$ & 32.3 & 62.6 & 36.5 \\
\hline Portugal & 28.3 & -10.4 & 14.8 & -17.3 \\
\hline Romania & 79.7 & -84.5 & -98.9 & -102.0 \\
\hline Slovak Republic & -2.4 & -14.0 & -105.8 & 13.3 \\
\hline Slovenia & 10.0 & -1.3 & -17.7 & 27.4 \\
\hline Spain & 14.5 & -7.6 & 12.2 & -4.4 \\
\hline Sweden & 7.9 & 6.2 & 25.3 & -12.7 \\
\hline United Kingdom & 1.0 & 1.2 & 23.1 & -11.3 \\
\hline
\end{tabular}

Unconditional: average overall score. Advanced secondary: student is native with both parents with advanced secondary education (reference group for the regressions). Low secondary: student is native with both parents with lower secondary education. College: student is native with both parents with college education.

Deviations from the average. 
The pattern is the same. What Tables 11-13 show is that the Spanish education system appears better at raising the performance of teenagers with low parental education levels than teenagers from more educated families. If this does not change in the future, rising parental education levels will not lead to Spanish PISA scores rising above the European average. In fact, when we ask what Spain's PISA performance would be if parental education levels were equal to the European average, we find that more than half of the European countries in our sample would continue to do better than Spain. ${ }^{18}$ Hence, there is considerable room for improvement.

\section{Table 13}

Average reading scores of native students at schools with less than $10 \%$ immigrant students (European sample)

\begin{tabular}{|c|c|c|c|c|}
\hline & Unconditional & $\begin{array}{l}\text { Advanced } \\
\text { secondary }\end{array}$ & $\begin{array}{l}\text { Low } \\
\text { secondary }\end{array}$ & College \\
\hline Austria & 5.2 & 9.7 & 6.8 & -1.4 \\
\hline Belgium & 15.9 & 30.5 & 41.4 & 28.5 \\
\hline Czech Republic & -2.3 & -4.1 & 20.0 & -3.1 \\
\hline Denmark & 9.5 & -2.1 & -0.2 & 2.7 \\
\hline Estonia & 15.8 & 12.6 & 8.0 & 7.0 \\
\hline Finland & 61.9 & 33.1 & 57.2 & 38.1 \\
\hline France & 2.7 & 11.4 & 11.5 & 13.4 \\
\hline Germany & 10.0 & 38.9 & 3.9 & 29.0 \\
\hline Greece & -25.3 & -22.4 & -30.6 & -26.0 \\
\hline Hungary & -2.6 & -15.1 & -46.8 & 13.1 \\
\hline Ireland & 32.3 & 25.5 & 30.3 & 28.0 \\
\hline Italy & -16.4 & -4.6 & -9.5 & -26.6 \\
\hline Latvia & -5.5 & -17.2 & -19.1 & -15.2 \\
\hline Lithuania & -14.9 & -41.7 & -49.2 & -22.9 \\
\hline Luxembourg & -5.6 & 41.8 & 92.2 & 15.7 \\
\hline Netherlands & 21.8 & 17.3 & 46.0 & 20.4 \\
\hline Portugal & -12.7 & 4.1 & 29.4 & 3.8 \\
\hline Romania & -89.0 & -90.6 & -118.0 & -116.0 \\
\hline Slovak Republic & -18.6 & -33.1 & -103.0 & -1.9 \\
\hline Slovenia & 9.4 & -5.0 & -22.2 & 24.6 \\
\hline Spain & -24.1 & -16.6 & 7.9 & -18.1 \\
\hline Sweden & 22.3 & 19.8 & 27.1 & 1.7 \\
\hline United Kingdom & 10.1 & 7.7 & 17.2 & 5.0 \\
\hline
\end{tabular}

Unconditional: average overall score. Advanced secondary: student is native with both parents with advanced secondary education (reference group for the regressions). Low secondary: student is native with both parents with lower secondary education. College: student is native with both parents with college education.

Deviations from the average.

18 In Appendix Figures A1-A3 and Tables A49-A57 we show the calculations for the shift-share analysis when we use the shares corresponding to the European average. 
Tables 14-16 contain the average PISA scores of native Catalan teenagers who attend schools with less than 10\% immigrants and have both parents with lower secondary school, upper secondary school, or college education. The logic of the tables follows Tables 11-13 exactly. Regarding science and math, it can be seen that Catalonia does below the average in each group. It can therefore not be expected that Catalan PISA scores in science and math will converge to the average as parental education levels catch up. The pattern is different for reading, where Catalan teenagers do better than average once parental education levels are controlled for. Hence, in reading, Catalan scores should rise above average as parental education levels catch up.

\section{Table 14}

Average science scores of native students at schools with less than 10\% immigrant students (regions/countries sample)

$\begin{array}{lcccc} & \text { Unconditional } & \begin{array}{c}\text { Advanced } \\ \text { secondary }\end{array} & \begin{array}{c}\text { Low } \\ \text { secondary }\end{array} & \text { College } \\ \text { Denmark } & -8.0 & -21.5 & -33.9 & -10.5 \\ \text { Flanders } & 25.3 & 16.8 & 21.3 & 25.2 \\ \text { Lombardy } & -4.8 & 17.0 & -0.2 & 0.6 \\ \text { Andalusia } & -30.1 & -17.9 & -11.6 & -28.2 \\ \text { Aragon } & 9.5 & 13.6 & 5.2 & 10.8 \\ \text { Asturias } & 4.6 & -6.0 & -5.4 & 5.0 \\ \text { Cantabria } & 5.5 & 0.2 & 0.9 & 12.6 \\ \text { Castile and Leon } & 16.0 & 10.1 & 20.1 & 11.0 \\ \text { Catalonia } & -12.5 & -3.1 & -14.7 & -9.1 \\ \text { Galicia } & 0.6 & -7.0 & 12.9 & -14.2 \\ \text { La Rioja } & 15.7 & 34.8 & 13.3 & 6.6 \\ \text { Navarre } & 7.4 & -0.7 & 10.1 & 1.4 \\ \text { Basque Country } & -9.2 & -17.1 & -1.7 & -17.9 \\ \text { Rest of Spain } & -20.0 & -19.2 & -16.3 & 6.8\end{array}$

Unconditional: average overall score. Advanced secondary: student is native with both parents with advanced secondary education (reference group for the regressions). Low secondary: student is native with both parents with lower secondary education. College: student is native with both parents with college education.

Deviations from the average. 


\section{Table 15}

Average math scores of native students at schools with less than $10 \%$ immigrant students (regions/countries sample)

$\begin{array}{lccrr} & \text { Unconditional } & \begin{array}{r}\text { Advanced } \\ \text { secondary }\end{array} & \begin{array}{r}\text { Low } \\ \text { secondary }\end{array} & \text { College } \\ \text { Denmark } & & & & \\ \text { Flanders } & 11.0 & -1.5 & -14.8 & 2.6 \\ \text { Lombardy } & 41.4 & 36.1 & 28.6 & 43.6 \\ \text { Andalusia } & -15.3 & 2.8 & -5.1 & -0.2 \\ \text { Aragon } & -39.3 & -25.4 & -29.0 & -43.4 \\ \text { Asturias } & 10.6 & 11.6 & 10.4 & 10.8 \\ \text { Cantabria } & -4.7 & -18.5 & -15.3 & -7.6 \\ \text { Castile and Leon } & -0.5 & -2.0 & -10.8 & 6.0 \\ \text { Catalonia } & 13.1 & 4.5 & 16.1 & 11.9 \\ \text { Galicia } & -14.3 & -14.2 & -11.7 & -3.7 \\ \text { La Rioja } & -8.2 & -13.5 & -0.3 & -23.3 \\ \text { Navarre } & 23.9 & 38.1 & 30.7 & 5.4 \\ \text { Basque Country } & 13.0 & 12.4 & 18.7 & 16.3 \\ \text { Rest of Spain } & -1.0 & -3.9 & -1.9 & -9.4 \\ & -29.5 & -26.4 & -15.5 & -9.1\end{array}$

Unconditional: average overall score. Advanced secondary: student is native with both parents with advanced secondary education (reference group for the regressions). Low secondary: student is native with both parents with lower secondary education. College: student is native with both parents with college education.

Deviations from the average.

\section{Table 16}

Average reading scores of native students at schools with less than $10 \%$ immigrant students (regions/countries sample)

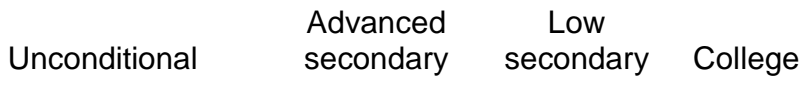

$\begin{array}{lrrrr}\text { Denmark } & 13.6 & -0.6 & -18.7 & 11.6 \\ \text { Flanders } & 41.1 & 38.6 & 23.6 & 48.5 \\ \text { Lombardy } & 9.6 & 29.7 & 14.1 & 12.8 \\ \text { Andalusia } & -36.3 & -25.9 & -27.5 & -38.8 \\ \text { Aragon } & 2.4 & 5.9 & 0.3 & -1.0 \\ \text { Asturias } & -3.7 & -12.7 & -0.4 & -7.6 \\ \text { Cantabria } & -6.2 & -14.5 & -14.2 & 2.4 \\ \text { Castile and Leon } & -2.8 & -10.1 & -0.4 & -12.0 \\ \text { Catalonia } & -4.1 & 11.7 & 2.6 & 4.8 \\ \text { Galicia } & -2.2 & -15.6 & -2.0 & -16.6 \\ \text { La Rioja } & 10.7 & 30.4 & 19.7 & 2.3 \\ \text { Navarre } & -0.4 & -11.2 & 9.4 & -5.8 \\ \text { Basque Country } & 6.5 & -2.1 & 5.6 & 5.0 \\ \text { Rest of Spain } & -28.3 & -23.7 & -12.2 & -5.3\end{array}$

Unconditional: average overall score. Advanced secondary: student is native with both parents with advanced secondary education (reference group for the regressions). Low secondary: student is native with both parents with lower secondary education. College: student is native with both parents with college education.

Deviations from the average. 


\section{School Expenditures and School Quality}

The academic literature tends to find weak effects of educational expenditures on school performance, and this remains true when examining the PISA data across countries. ${ }^{19}$

\section{Figure 15}

PISA scores versus total secondary education expenditures by student (European sample)

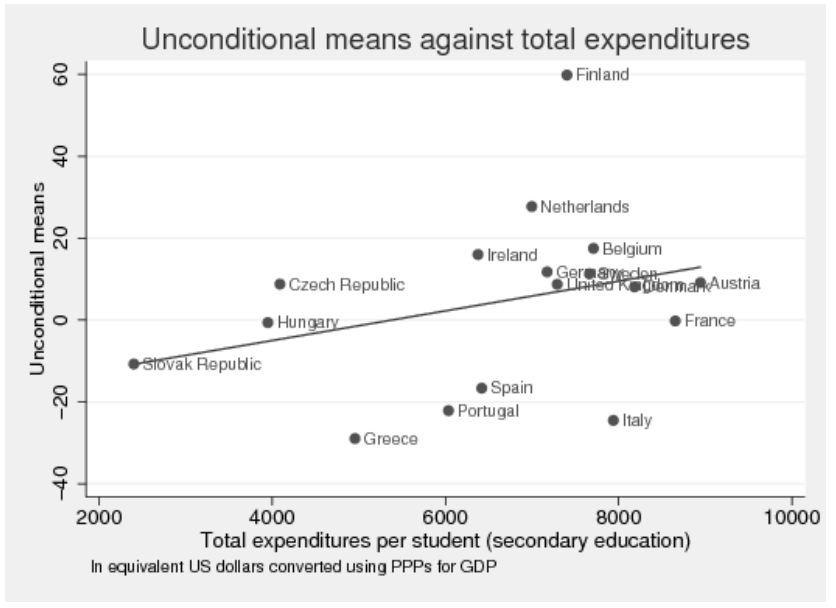

Note: For Portugal and Italy public institutions only. OECD countries (Luxembourg has been omitted).

Figure 15 plots secondary school expenditures, adjusted for purchasing power differences, against the unconditional PISA results. ${ }^{20}$ The figure averages the results in science, math, and reading and measures countries relative to the cross-country average. It can be seen that the relationship between school expenditures and PISA results is weak (in fact it is statistically insignificant). Figure 16 repeats the analysis but using PISA scores that are adjusted for parental education levels and immigration using the regression method (our first approach). Interestingly, the relationship between school expenditures and PISA results now becomes statistically significant at the $97.5 \%$ confidence level. ${ }^{21}$ But the slope of the regression line is small, 0.0032. This implies that a 1000 dollar increase in expenditures per pupil only yields a 3.2 point increase in PISA scores.

\footnotetext{
${ }^{19}$ For reviews see Card, D. and A. B. Krueger (1996) and Hanushek, E. (1996).

${ }^{20}$ The expenditure data come from OECD (2006a).

${ }^{21}$ This is consistent with Fuchs, T. and L. Woessmann (2004).
} 


\section{Figure 16}

Adjusted PISA scores versus total secondary education expenditures by student (European sample)

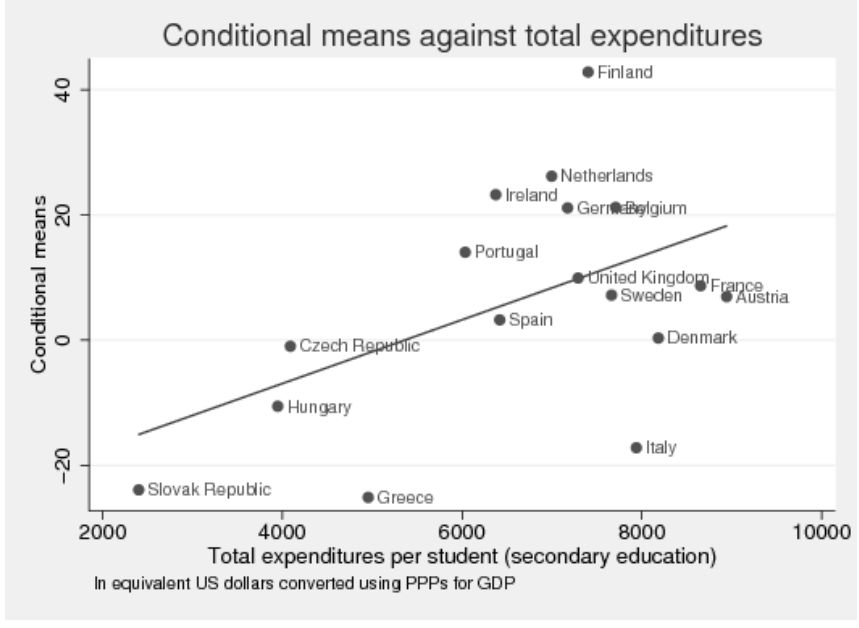

Note: For Portugal and Italy public institutions only.

OECD countries (Luxembourg has been omitted).

Figures 17 and 18 consider the relationship between secondary school expenditures and PISA scores across Spanish regions. The expenditure data come from De la Fuente, Domenech, and Jimeno (2003). ${ }^{22}$ Figure 17 considers the unconditional PISA score, while Figure 18 considers the PISA score controlling for parental education and immigration status. In both cases we are averaging across the science, math, and reading results. The data yields a positive correlation between expenditures and PISA scores in both cases but the link is never statistically significant at standard confidence levels.

\section{Figure 17}

PISA scores versus average secondary education expenditures by student (Spanish regions)

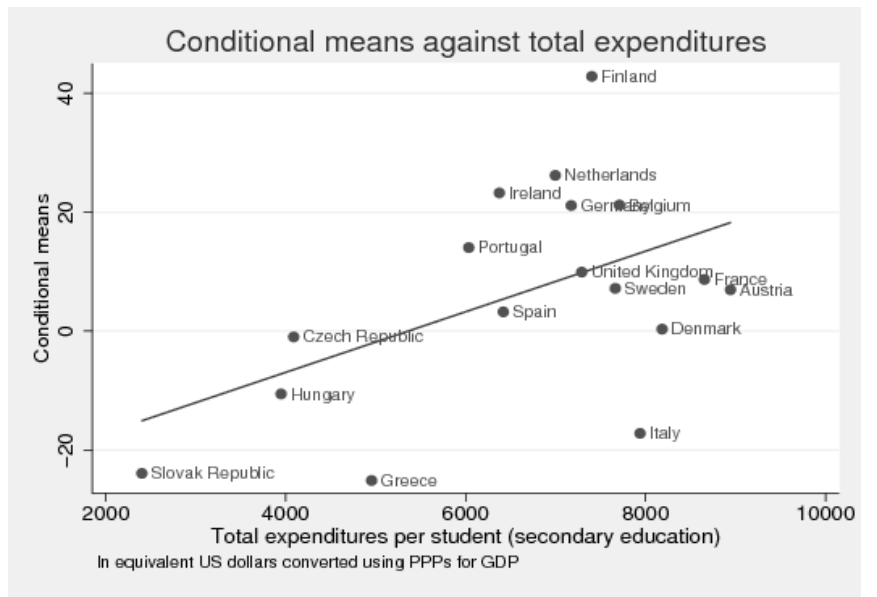

Source: Average expenditures from De la Fuente, Domenech, and Jimeno (2003).

\footnotetext{
${ }^{22}$ De la Fuente, A. et al. (2003).
} 


\section{Figure 18}

Adjusted PISA scores versus average secondary education expenditures by student (Spanish regions)

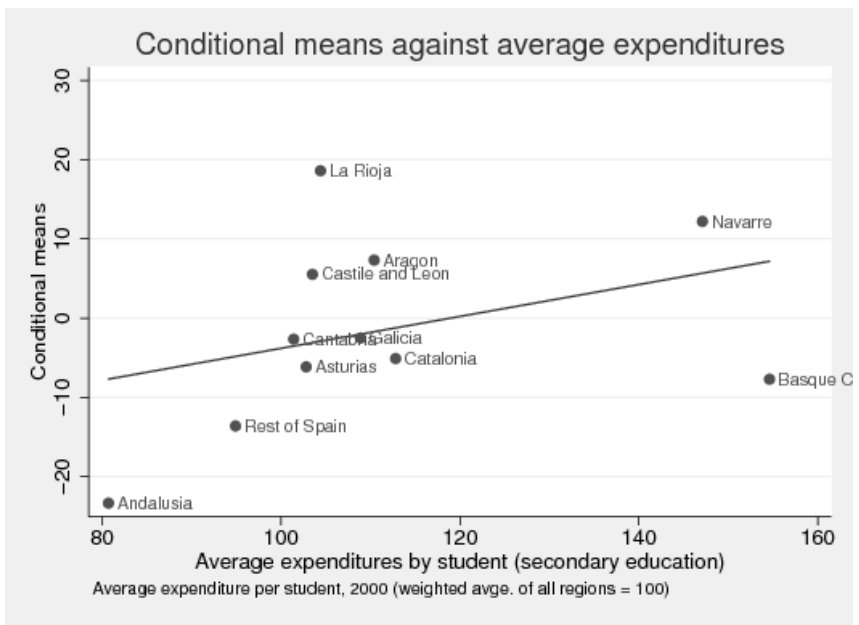

Source: Average expenditures from De la Fuente, Domenech, and Jimeno (2003).

The setting that according to the academic literature is most conducive to school quality is school autonomy subject to performance evaluation. ${ }^{23}$ Unfortunately, however, there is insufficient data on school and student characteristics to evaluate these hypotheses specifically for Catalonia and Spain. Making progress in understanding the determinants of school quality within Catalonia or Spain will require that policy makers decide to implement rigorously designed school evaluation programs.

\section{Conclusions}

There is a sizable increase in the Spanish PISA scores relative to the rest of Europe when parental schooling is controlled for. But Spain's performance is rather poor to start out with and only rises to about average when accounting for parental education levels (somewhat above average in science and math and about average in reading). Another way to see that there is considerable room for improvement is to note that, compared to the European average, Spain does relatively poorly when we consider teenagers whose parents have an upper secondary or a college education. Immigration plays almost no part in Spain's comparative PISA performance, as the differences between Spain and the rest of Europe are small.

Accounting for parental education levels leads to small improvements in the Catalan PISA score. Compared to other Spanish regions, Flanders, Lombardy, and Denmark, Catalonia continues to be below average in science and math. In reading, Catalonia starts only slightly below average and rises just above the average when parental education is controlled for. Moreover, the below average performance of Catalonia in science and math is not due to immigration or the concentration of immigrants at some schools. Making progress in understanding why Catalonia does worse than other Spanish regions that are similar in many respects will require a detailed evaluation of individual school data.

\footnotetext{
${ }^{23}$ Rivkin, S. et al. (2005).
} 


\section{References}

Betts, J. R. and R. W. Fairlie (2003), "Does Immigration Induce 'Native Flight' from Public Schools into Private Schools.” Journal of Public Economics, Vol. 87, pp. 987-1012.

Card, D. and A. B. Krueger (1996), "School Resources and Student Outcomes: An Overview of the Literature and New Evidence from North and South Carolina," Journal of Economic Perspectives, American Economic Association, Vol. 10 (4), Fall, pp. 31-50.

De la Fuente, A., R. Domenech, and J.F. Jimeno (2003), "Human capital as a factor of growth and employment at the regional level. The case of Spain", Working Papers, Institut d'Anàlisi Econòmica.

Fuchs, T. and L. Woessmann (2004), "What Accounts for International Differences in Student Performance? A Re-Examination Using PISA Data,” IZA Discussion Paper No. 1287.

Generalitat de Catalunya (2007), “Presentació de l'Informe PISA,” December 4.

Hanushek, E. (2005), "The Economics of School Quality," German Economic Review, 6 (3), pp. 269-286.

Hanushek, E. (1996), "Measuring Investment in Education," The Journal of Economic Perspectives, American Economic Association, Vol. 10, No. 4, Autumn, pp. 9-30.

OECD (2006a), "Education at a Glance.”

OECD (2006b), "Programme for international student assessment (PISA)."

Rivkin, S., E. Hanushek, and J. F. Kain, (2005), "Teachers, Schools, and Academic Achievement.” Econometrica, The Economic Society, Vol. 73 (2), March, pp. 417-458. 